\title{
Berthold of Moosburg, Nicholas of Cusa, and Marsilio Ficino as Historians of Philosophy
}

\author{
Stephen Gersh \\ University of Notre Dame
}

\section{Introduction}

Berthold of Moosburg, Nicholas of Cusa, and Marsilio Ficino are undoubtedly the three pre-eminent Platonists of the fourteenth and fifteenth centuries ranked in chronological order. However, it is a rather surprising that none of the three acknowledges the influence of his predecessor within the group and indeed they scarcely mention one another. Nicholas of Cusa discusses the erroneous assumptions concerning God's presence in all things when this notion is not approached with "learned ignorance" and the consequent justification with which certain saints argue that the intellectual light should be withdrawn from those with weak mental eyes. This intellectual light is then illustrated with a list of authors and books including the commentaria Iohannis de Mossbach in propositiones Procli. ${ }^{1}$ Marsilio Ficino responds in a letter dated 12 June 1489 to an inquiry by his friend Martin Prenninger regarding the availability of books in Latin setting out the essentials of Platonic philosophy. He supplies a list of books including both scholastic and more modern authors that ends with quaedam speculationes Nicolai Cusii Cardinalis. ${ }^{2}$ These references of Nicholas to Berthold and of Ficino to Nicholas together with the absence of any reference in Ficino to Berthold do not take us beyond the level of basic bibliography. Indeed, the bibliography is rather defective given that

1 Nicholas of Cusa, Apologia doctae ignorantiae, h II, p. 30, l. 1-3 in Nicholas of Cusa, Opera omnia, iussu et auctoritate Academiae Heidelbergensis ad codicum fidem edita (Hamburg: Meiner, 1932-2006) [= h]. This Latin edition together with English and German translations can be accessed at www.cusanus-portal.de.

2 Marsilio Ficino, Epistulae, in Marsilii Ficini [...] opera et quae hactenus extitere et quae in lucem nunc primum prodiere omnia [...] (Basel: Heinrich Petri, 1576 [photographic reprint Torino: Bottega d'Erasmo, 1959]), lib. IX, 12, p. 899. Henceforth cited as Opera omnia. 
the names of Berthold and Nicholas are both misspelled by the authors who cite them, or at least by their copyists and editors. ${ }^{3}$

The present essay will leave to those who consider the general psychology of authorship the question why writers who clearly have some knowledge of each other's works and share a philosophical agenda do not explicitly make common cause. Instead, we will attempt to make a comparative study of the three authors that elucidates both their similarity of philosophical method and doctrine and also their numerous subtle deviations in approach. The main points of similarity are first, that for them writing the history of philosophy is part of doing philosophy itself, this being obvious in the case of Berthold and Ficino and also arguable in that of Nicholas; second, that for them Platonism is the closest philosophy to Christianity according to the authority of Augustine and according to the example of Dionysius the Areopagite. The subtle deviations are numerous and include: first, Berthold and Ficino are both explicit commentators - lemmatic in the former case and discursive in the latter -, whereas Nicholas is not primarily an exegete. Second, Nicholas and Ficino emphasise the concordance of Plato and Aristotle whereas Berthold stresses their disagreement. Third, Nicholas and Ficino are anti-Scholastic in underlying intent, Nicholas being openly subversive - especially via his doctrines of the coincidence of opposites and his methodology based on conjecture - and Ficino being more subtly evasive, whereas Berthold remains more embedded in the scholastic context. Fourth, Nicholas and Ficino avoid the axiomatic method of philosophical expression, whereas Berthold assigns it prominence. Finally, both Berthold and Nicholas depend on the medieval "Platonic" corpus especially Augustine, Dionysius the Areopagite and Proclus -, whereas Ficino also introduces works newly translated from the Greek.

Against the background of these writers' common assumptions regarding the importance of the history of philosophy and of their particular commitment to a belief in the inherent sympathy of Platonism and Christianity, this essay will examine how Berthold, Nicholas, and Ficino collectively albeit with the variety of subtle deviations mentioned above - approach the Hermetica, Plato, and Proclus, making briefer reference to their readings of the Pythagoreans, the Latin Platonists, and the Greek Neoplatonists for reasons of space. With an appropriate caveat about simplification, we will conclude that with respect to their exploitation of these intertextual foundations of Platonic philosophy, Nicholas and Ficino are closer to one another than is Berthold to either Nicholas or Ficino.

3 It is "John of Mossbach" rather than Berthold of Moosburg, while "Cusa" appears in a strange variety of spellings in the early Ficino printings. 
The writings originating in late antiquity and the Middle Ages and attributed to the mythical figure of Hermes Trismegistus play a major role in establishing the notion of "Platonism" for our three philosophers. The importance of these writings stems from the venerable authority attributed to their assumed ancient author, although there was always a certain measure of controversy surrounding their value. ${ }^{4} \mathrm{~A}$ favourable presentation of Hermes and his works can be found primarily in Lactantius who in his Divinae institutiones reports that Trismegistus often described the excellence and majesty of the one God, called him by the names that Christians use: namely, "God" and "Father," and also declared that the one God actually has no name. ${ }^{5}$ In addition, the same church father quotes a work by Trismegistus called the Logos Teleios in which the first God is said to have made a second God who was his Son ${ }^{6}$ and to have foretold the restoration of the world: a point on which he was in agreement with the Sibyl. ${ }^{7}$ A more ambivalent presentation of Hermes and his writings occurs in Augustine. On the negative side, the bishop of Hippo quotes the opinion of the Egyptian Hermes called "Trismegistus" concerning demons from a Latin translation of his work entitled Asclepius. ${ }^{8}$ Hermes here maintains that there are two classes of gods: created by the supreme God and created by men respectively, the latter being idols dedicated to gods and animated by them. ${ }^{9}$ Augustine clearly finds this author to be rather problematic for, although the latter rightly prophesies the time when the pagan religion will be conquered by a new belief, he does not explicitly name the latter as Christianity and seems to deplore the forthcoming events. This would indicate that the prophecy was

4 For biographical information about Hermes see Lactantius, Divinae institutiones, lib. I, c. 6, reporting Cicero's reference to five Mercuries, the fifth being the one who slew Argus and therefore fled to Egypt and gave laws and letters to the Egyptians. He was called Thoth by Egyptians, was of great antiquity, and was imbued with so much learning that he acquired the name "Trismegistus"; De ira Dei, c. 11, Trismegistus more ancient than Plato and Pythagoras; Augustine, De civitate Dei, lib. XviII, c. 39, reporting that Trismegistus lived long before the sages and philosophers of Greece but after Abraham, Isaac, Jacob, Joseph, and even Moses. At the time when Moses was born there lived Atlas, Prometheus' brother, a great astronomer. He was grandfather by the mother's side to the elder Mercury who begat the father of this Trismegistus.

5 Lactantius, Divinae institutiones, lib. I, c. 6.

6 Lactantius, Divinae institutiones, lib. IV, c. 6.

7 Lactantius, Divinae institutiones, lib. viI, c. 18.

8 Augustine's reference here is to Hermes Latinus, Asclepius, eds A.D. Nock, A.-J. Festugière, Corpus Hermeticum, vol. 2 (Paris: Les Belles Lettres, 1973), c. 23-24, p. 325, l. 4-p. 326, l. 2 .

9 Augustine, De civitate Dei, lib. VIII, c. 23. 
revealed to him not by the Holy Spirit but by demons..$^{10}$ On the positive side, the church father cites Hermes Trismegistus' statements to the effect that there is one true God who is the artificer of the universe as being close approximations to the truth. In the light of such statements, Augustine finds it very surprising that the same author allows men to be subjected to man-made gods and bewails the destruction of this idolatrous religion.

During the period under review in the present study, we can distinguish two phases in the interpretation of Hermes Trismegistus based on the range of texts available: ${ }^{11}$ a medieval phase and a Renaissance phase. ${ }^{12}$ In the medieval phase, the main texts are the Asclepius already mentioned - a genuinely ancient text whose Latin translator was often thought to be Apuleius ${ }^{13}$ - and two pseudo-antique medieval works: the Liber XXIV philosophorum and the De VI rerum principiis, the former being often cited without specific mention of Hermes as author. ${ }^{14}$ These texts are all used by Berthold of Moosburg who cites them often through intermediate sources such as Alan of Lille, Albert the Great, and Thomas of York. ${ }^{15}$ They are also used by Nicholas of Cusa who generally cites them directly, as his extant Ms glosses on the Asclepius would seem to indicate. ${ }^{16}$ In the Renaissance phase, the main texts are the Asclepius and the medieval treatises once again, although these are now supplemented by the Pimander, i.e. Ficino's translation of the Greek Corpus Hermeticum.

10 The discussion continues down to De civitate Dei, lib. virI, c. 26 quoting Asclepius, cc. 24-25, p. 326, l. 15-329, l. 23 .

11 On the Ms tradition see P. Lucentini, V. Perrone Compagni, "I manoscritti dei testi ermetici latini", in P. Lucentini, I. Parri, V. Perrone Compagni (eds), Hermetism from Late Antiquity to Humanism. La tradizione ermetica dal mondo tardo-antico all'Umanesimo = Atti del Convegno internazionale di studi, Napoli 20-24 novembre 2001 (Turnhout: Brepols, 2003), p. 715-745.

12 The phases are mainly distinguished by the range of texts available.

13 For a survey see C. Gilly, "Die Überlieferung des Asclepius im Mittelalter", in R. van den Broek, C. van Heertum (eds), From Poimandres toJacob Böhme. Gnosis, Hermetism and the Christian Tradition (Leiden: Brill, 200o), p. 336-367.

14 For a survey see Hermes Latinus, Il Libro dei ventiquattro filosofi, ed. P. Lucentini (Milano: Adelphi, 1999), containing the study: "La fortuna del 'Libro dei ventiquattro filosofi' nel Medioevo", p. 103-150.

15 For citation of these three Hermetic texts by Thomas of York see D. Porreca, "Hermes Trismegistus in Thomas of York. A 13th-Century Witness to the Prominence of an Ancient Sage", in Archives d'histoire doctrinale et littéraire du Moyen Âge 72(2005), p. 147-275. See also L. Sturlese, "Saints et magiciens. Albert le Grand en face d'Hermès Trismégiste", in Archives de philosophie 43(1980), p. 615-634.

16 See note 34 . 


\subsection{Berthold of Moosburg}

Berthold of Moosburg cites the Asclepius with bibliographical precision as Trismegistus ad Asclepium De Hedera, id est, De Deo deorum. ${ }^{17}$ The importance of this work for him is indicated by his use of two passages as the basis of an informal lemmatic commentary setting out his doctrine of the macrocosm and microcosm in the Prologue to his Expositio. The passage dealing with the macrocosm reads: "Mundus est opus Dei immutabile, gloriosa constructio, bonum multiformi imaginum varietate compositum, machina voluntatis Dei suo operi absque invidia suffragantis" ("the world is an immutable work of God, a glorious construction, a good composed of a multiform variety of images, a mechanism of the will of God who ungrudgingly supports his work"). ${ }^{18}$ The first lemma extracted from this, opus, is initially glossed by noting that the Hermetic author refers to a "work" rather than to a "creature" because of the peculiar status of the primordial causes: a notion derived by the commentator from the Clavis physicae of "Theodorus". ${ }^{19}$ The gloss is next expanded intertextually by Berthold who observes that this same work is perfectissimum according to Plato's Timaeus, pulcherrimum according to Boethius' De consolatione philosophiae, and ordinatissimum according to Augustine and the Asclepius itself. ${ }^{20}$ There follows a series of lemmatic comments of a similar kind based on the terms immutabile, gloriosa constructio, bonum multiformi imaginum varietate compositum, and machina voluntatis dei ${ }^{21}$ after which the commentator returns to his base text using a different methodology. The complementary passage dealing with the microcosm reads: "Homo est nexus Dei et mundi super mundum per duplicem indagationem existens [...] et hoc modo mundi gubernator proprie vocatur. Subnexus autem Deo, pulchritudines eius non immersas mundo [...] accipiens per similitudinem divinam" ("man is the bond between God and the world, existing above the world in terms of a

17 Berthold of Moosburg, Expositio super Elementationem theologicam Procli. Prologus, Propositiones 1-13, eds M.R. Pagnoni-Sturlese, L. Sturlese (Hamburg: Meiner, 1984), Expositio tituli K, p. 47, l. 368-369, using the reading De Hedera of codex v. On the titles see Porreca, "Hermes Trismegistus and Thomas of York", p. 150-151.

18 Berthold of Moosburg, Expositio, Prologus 8, p. 14, 1. 296-299. The passage summarized by Berthold is Asclepius, c. 25, p. 328. 1. 20-23.

19 Berthold of Moosburg, Expositio, Prol. 9, p. 14, l. 300-302. Several other texts influenced by Eriugena are also cited.

20 The passages cited are Calcidius, Commentarius in Timaeum, ed. J.H. Waszink, Timaeus a Calcidio translatus commentarioque instructus (London / Leiden: Warburg Institute / Brill, 1962), p. 23, 1. 16-2o (= Plato, Timaeus, 3od-31a); Boethius, De consolatione philosophiae, ed. C. Moreschini (München / Leipzig: Saur, 2005), lib. III, m. 9, p. 8o, 1. 7; and Augustine, De ordine, passim.

Berthold of Moosburg, Expositio, Prol. 10-13, p. 16, 1. 363-p. 23, l. 569. 
twofold investigation [...] and in this way he is properly called the governor of the world. Bound in subordination to God, he receives the latter's beauties that are not immersed in the world through his similarity to the divine"). This passage is actually not a direct quotation from the Asclepius but a summary of the latter in Albert the Great's Metaphysica..$^{22}$ The first lemma extracted from it, nexus dei et mundi, ${ }^{23}$ is initially glossed by noting that the Hermetic writer is alluding to the four principal parts of the totality: namely, body, soul, intellect, and unity - a division derived from Proclus rather than the Asclepius itself. After suggesting that the first three terms require little comment, Berthold expands the gloss intertextually by citing for an explanation of unity Proclus' De providentia et fato and noting that Dionysius' De divinis nominibus agrees with this teaching, ${ }^{24}$ the discussion continuing with the statement that there is an assimilation of the microcosm to God through unity and intellect and to the world through soul and body. There follows a series of lemmatic comments of a similar kind based on the terms duplicem indagationem, gubernator, subnexus Deo, and pulchritudines non immerses mundo. ${ }^{25}$

In addition to the Asclepius, Berthold makes a number of references to the medieval Hermetic texts. ${ }^{26}$ From the Liber XXIV philosophorum he quotes the VII regula Trismegisti stating that God is "a beginning without beginning, a process without variation, an end without end" ("principium sine principio, processus sine variatione, finis sine fine"), and per vi ibidem the statement that he is that "in comparison with which substance is accident and accident is nothing" ("cuius comparatione substantia est accidens, accidens vero nihil"). ${ }^{27}$

22 Berthold of Moosburg, Expositio, Prol. 14, p. 23, 1. 570-577. The passage summarised by Berthold is Albert the Great, Metaphysica, ed. B. Geyer (Münster i.W.: Aschendorff, 1960), lib. I, tr. 1, c. 1, p. 2, l. 5-15, which itself follows Asclep., c. 6-10, p. 301, l. 18-309, l. 4.

23 Berthold of Moosburg, Expositio, Prol. 15, p. 23, l. 578-579.

24 The passages cited are Proclus, De X dubitationibus circa providentiam, ed. D. Isaac (Paris: Les Belles Lettres, 1977), c. 10, §64, p. 134, l. 12-14; and Dionysius, De divinis nominibus, c. $7, \S 1,865$ C.

25 Berthold of Moosburg, Expositio, Prol. 16-18, p. 23, l. 6o4-p. 27, l. 734.

26 On Berthold's use of the medieval Hermetica see the series of studies by A. Sannino, "Berthold of Moosburg's Hermetic Sources", in Journal of the Warburg and Courtauld Institutes 63(2000), p. 243-258; A. Sannino, "Il concetto ermetico di natura in Bertoldo di Moosburg", in P. Lucentini, I. Parri, V. Perrone Compagni (eds), Hermetism from Late Antiquity to Humanism, p. 203-221; A. Sannino, "Il Liber viginti quattuor philosophorum nella metafisica di Bertoldo di Moosburg", in A. Beccarisi, R. Imbach, P. Porro (eds), Per perscrutationem philosophicam. Neue Perspektiven der mittelalterlichen Forschung. Loris Sturlese zum 6o. Geburtstag gewidmet (Hamburg: Meiner, 2008), p. 252-272.

27 Berthold of Moosburg, Expositio, Expos. tit., I, p. 46, 1. 332-335. The passages cited are Liber XXIV philosophorum, in Hermes Latinus, Le Livre des XXIV philosophes, ed. F. Hudry (Grenoble: Millon, 1989), maxim 6, p. 108 and maxim 7, p. 111. 
Without attribution he also quotes the statement in the same work that God is "an infinite sphere whose centre is everywhere but whose circumference is nowhere" ("sphaera infinita, cuius centrum est ubique, circumferentia vero nusquam"). ${ }^{28}$ From the De vI rerum principiis he quotes a variety of teachings including the notions that intellect is transformed from on high into divine knowledge, that intellect so transformed investigates what the Good's causality and effectivity is, ${ }^{29}$ that the Good is the creator of all things and the plenitude of knowledge, and that the Good is the mind that discharges its function without any fatigue. ${ }^{30}$

\subsection{Nicholas of Cusa}

Nicholas of Cusa's interest in the tradition of philosophical Hermetica can be documented throughout his career, starting from some of the earliest sermons to the De ludo globi of $1462-3 .{ }^{31}$ A passage in his Apologia doctae ignorantiae shows decisively albeit indirectly the importance that he attaches to this literature by comparing the dialogic and didactic relation between Hermes and "Aesculapius" to that between Dionysius the Areopagite and Timothy and even to that between Christ and St. Paul. ${ }^{32}$ The earlier work of which the Apologia is a defence - De docta ignorantia - had already contained some striking references to the Asclepius. In support of his argument for the lack of distinction in the Absolute Maximum, Nicholas notes that "for this reason, Hermes Trismegistus rightly says that 'since God is all things, he has no proper name, for it would be necessary either to give God every name or call all things by his name" ("quoniam Deus est universitas rerum, tunc nullum nomen proprium est eius, quoniam aut necesse esset omni nomine Deum aut omnia eius nomine

28 Berthold of Moosburg, Expositio, Prol. 11, p. 18, l. 419-420. The passage cited is Lib. XXIV Philos., maxim 2, p. 208.

29 Berthold of Moosburg, Expositio, 11F, p. 192, l. 261-265: sicut dicit Trismegistus De sex principiis cap. 1. The passage cited is Hermes Latinus, Liber de VI rerum principiis, eds P. Lucentini, M.D. Delp (Turnhout: Brepols, 2006), part I, c. 2, 1. 48-50.

30 Berthold of Moosburg, Expositio, 11F, p. 193, 1. 296-305. The passages cited are Lib. De VI rerum princ., part I, c. 2, l. 4-10; part I, c. 2, l. 44-48; part I, c. 3, l. 1-8; part I, c. 3, l. 21-24.

31 For Nicholas' reading of the testimonies of Lactantius and Augustine concerning Hermes Trismegistus see Sermo I, §2 [December 1430], eds R. Haubst, M. Bodewig (Hamburg: Meiner, 1977). However, he adopts a more circumspect view of some doctrines in the Hermetic books in Sermo II, §2 [January 1431]. The influence of Hermetic texts on Nicholas has been studied by A. Minazzoli, "L'héritage du Corpus Hermeticum dans la philosophie de Nicolas de Cues", in La Ciudad de Dios 205(1992), p. 101-122; P. Arfé, "Ermete Trismegisto e Nicola Cusano", in P. Lucentini, I. Parri, V. Perrone Compagni (eds), Hermetism from Late Antiquity to Humanism, p. 223-243; and G. Federici Vescovini, Nicolas de Cues (Paris: Vrin, 2016), p. 53-64.

Nicholas of Cusa, Apologia doctae ignorantiae, h II, p. 5, l. 21-23. 
nuncupari"). ${ }^{33}$ Whereas this quotation is obviously drawn directly from the Asclepius - a work on which Nicholas' manuscript glosses survive,$-{ }^{34}$ another passage is probably taken indirectly through Thierry of Chartres. In developing his account of the fourfold structure of the Contracted Maximum, Nicholas quotes the view of unnamed authorities that the movement characteristic of the created world "is a certain spirit that is as though intermediate between matter and form [...] a spirit of connection which proceeds from both: namely, possibility and the world-soul" ("spiritus quidam esse, quasi inter formam et materiam medius [...] spiritus connexionis procedere ab utroque: scilicet, possibilitate et anima mundi"). ${ }^{35}$

Nicholas is not deterred from citing some of the most controversial and the most enigmatic parts of the Asclepius. In De beryllo he includes among a set of premises to be employed in the explanation of the hermeneutical device called the "intellectual beryl" the statement of Hermes Trismegistus that "man is a second god" (hominem esse secundum deum) and then glosses this by arguing that, just as God is the creator of "real beings" (entia realia) and natural forms, so is man the creator of "conceptual beings" (rationalia entia) and artificial forms: an analogy that underlies his methodology of conjecture. ${ }^{36}$ In $D e$ ludo globi he destabilizes the notion of the world's physically precise sphericity by endorsing Mercury's view that it is not the world's roundness "of itself" ( $e x$ se) but only the forms of things contained in it that are actually visible. ${ }^{37}$

It is consistent with his all-pervasive epistemology exploiting the "coincidence of opposites" that Nicholas should especially gravitate towards the paradoxical utterances forming the quasi-definitions of God in the Liber XXIV philosophorum. In the second book of De docta ignorantia he attributes to an anonymous sage the fourteenth proposition of that work stating that "God is the opposite of nothing with being as the intermediary" (Deus est oppositio

33 Nicholas of Cusa, De docta ignorantia, h I, lib. I, c. 24, p. 48, l. 13-15. The reference is to Asclepius, c. 20, p. 321, l. 5-9. See also Nicholas of Cusa, De beryllo, h XI/1, §13, l. 10-12.

34 See P. Arfé (ed.), Cusanus-Texte III. Marginalien. 5. Apuleius. Hermes Trismegistus. Aus Codex Bruxellensis 10054-56 (Heidelberg: Winter, 2004).

35 Nicholas of Cusa, De docta ignorantia, h I, lib. II, c. 10, p. 96, l. 14-p. 97, l. 17. The reference is to Asclep., c. 14, p. 313, l. 3-7 and l. 20-22; c. 16, p. 315, l. 13-16; c. 17, p. 315, l. 22-24 and p. 316, l. 3-4. Cf. Thierry of Chartres, Commentum super librum Boethii De Trinitate, ed. N.M. Häring, Commentaries on Boethius by Thierry of Chartres and His School (Toronto: Pontifical Institute of Medieval Studies, 1971), c. 4, p. 91-96.

36 Nicholas of Cusa, De beryllo, h xI/1, §7, l. 1-2. The reference is to Asclepius, c. 6, p. 301 , l. 18-p. 302, l. 2.

37 Nicholas of Cusa, De ludo globi, h IX, lib. I, §13, l. 15-17. The reference is to Asclepius, c. 17, p. 316, l. $5^{-10 .}$ 
nihil mediatione entis). ${ }^{38}$ In the same book he applies without attribution exactly as Berthold had done earlier in his Expositio - the second proposition: "God is an infinite sphere whose centre is everywhere but whose circumference is nowhere" by analogy to both the Absolute and the Contracted Maximum. ${ }^{39}$

\subsection{Marsilio Ficino}

The status of the Hermetica as a literary source was changed radically by Marsilio Ficino. ${ }^{40}$ In the proem to his translation and commentary on Plotinus' Enneads published in 1492, he describes the circumstances surrounding his commission almost thirty years earlier to translate the Greek Hermetic corpus, a manuscript of which had come into the possession of Cosimo de' Medici. ${ }^{41}$ The resulting Latin translation of the Greek text ${ }^{42}$ - to which he assigned the title of Pimander - is prefaced with a short argumentum summarising all the biographical and genealogical information about the mythical author that could be derived from Cicero, Lactantius, and Augustine. ${ }^{43}$ This short preface is the Florentine writer's only extended critical reflection on the Hermetica, since the annotations on the separate treatises that accompanied his translation in some of the early printings are in fact by Jacques Lefèvre d'Étaples.

It is the fact that Ficino here introduces some of his own most important ideas that makes this preface a document of real interest. He explains that the ancient author was called "thrice-greatest" (ter maximus) because he was considered to be the greatest philosopher, the greatest priest, and the greatest king - a detail important with respect to Ficino's view of the fusion of philosophy and religion. ${ }^{44}$ Regarding the character of Hermes, the commentator informs us that he was the first philosopher to transfer himself from physics

38 Nicholas of Cusa, De docta ignorantia, h I, lib. II, c. 2, p. 66, l. 11. The reference is to Liber XXIV philosophorum, maxim 14, p. 133.

39 Nicholas of Cusa, De docta ignorantia, h I, lib. II, c. 12, p. 103, l. 20-p. 104, l. 3. The reference is to Liber XXIV philosophorum, maxim 2, p. 95.

40 On the influence of Hermetica on Ficino see M.J.B. Allen, "Marsilio Ficino, Hermes Trismegistus and the Corpus Hermeticum", in J. Henry, S. Hutton (eds), New Perspectives on Renaissance Thought. Essays in the History of Science, Education and Philosophy in Memory of Charles B. Schmitt (London: Duckworth, 199o), p. 38-47; S. Gentile, C. Gilly (eds), Marsilio Ficino e il ritorno di Ermete Trismegisto. Marsilio Ficino and the Return of Hermes Trismegistus (Firenze: Centro Di, 1999).

41 Marsilio Ficino, In Enneadem I, ed. S. Gersh (forthcoming), proem §1.

42 Apparently because of a lacuna in his Greek manuscript, Ficino in his Pimander omits one treatise included in the modern edition.

43 Marsilio Ficino, Opera omnia, p. 1836.

44 However, the notion of Mercury's triple profession itself may have been derived from a similar suggestion at De VI rerum principiis, prol., l. 6-7. 
and mathematics to divine matters and the first to dispute widely regarding the majesty of God, the order of daemons, and the vicissitudes of souls. He adds that Hermes also speaks as a prophet in predicting the end of the old religion and rise of a new faith, the advent of Christ, the future judgment, and the resurrection. From these comments, it becomes apparent that Ficino is following the favourable view of Lactantius - i.e. that Hermes has definite proChristian tendencies - rather than the sceptical view of Augustine. Regarding the organization of the Hermetic corpus, the argumentum informs us that of their author's many books two are most important: one concerning the divine will and entitled Asclepius and another concerning the power and wisdom of God and entitled Pimander. It further notes that the former was translated into Latin by Apuleius, whereas the latter remained in Greek until it was brought to Italy by Leonardo of Pistoia and translated by Ficino on the orders of Cosimo de' Medici. Finally, we learn that Hermes is the founder of a tradition of "ancient theology" (antiqua theologia) which continued with Orpheus, Aglaophemus, Pythagoras, Philolaus, and Plato in a sixfold order - an idea crucial for Ficino's interpretation of the history of philosophy.

Despite completing a translation of the Greek Hermetic corpus, Ficino uses this material only to a limited extent in his own commentaries and treatises. ${ }^{45}$ It is not absolutely clear why this is the case, although possible reasons might include a desire to distance himself from medieval philosophical material that had by this time become a cliché - as he perhaps does also with Proclus' Elements of Theology-, and a feeling that he now also has better Greek writings - e.g. those of Plato and Plotinus - covering the relevant metaphysical topics. In fact, the one Hermetic passage that he exploits in a significant way is the controversial one in the Asclepius dealing with statue-making. ${ }^{46}$ In book three of his De Vita, Ficino presents this text from a novel intertextual perspective in arguing that Plotinus, in the Fourth Ennead, 47 "imitates Mercury"

45 The main importance of Hermes for Ficino seems to be as the founder of the tradition of "ancient theology" that is integral within the Florentine's view of the history of philosophy. However, from the time of the first version of Ficino's Philebus commentary and the Platonic Theology onwards, Hermes' position in that tradition is usurped - under the influence of Proclus and Plethon - by the equally mythical figure of "Zoroaster", the putative author of the Chaldaean Oracles.

$46 \quad$ See above.

47 The third book of Ficino's treatise was originally conceived as a commentary on Plotinus, Ennead IV.3.26 and appears as such in the dedication MS of his Plotinus translation and commentary but not in the editio princeps. 
(Mercurium imitatus) $)^{48}$ in illustrating the soul's acquisition of celestial gifts with the magi's capturing of something divine and wonderful in their statues. ${ }^{49}$ To some extent, this perfectly justifiable interpretation in relation to the original Plotinian discussion can be viewed as sanitising the Hermetic text by treating the animation of statues as a metaphor for a natural process rather than as literal account of an occult contrivance. ${ }^{50}$

\section{3}

\section{Pythagoreans}

The importance of Pythagoras and his followers for the development of philosophy before Plato was well established for later generations by the doxographies in writers such as Augustine and Macrobius and by the role of "Timaeus" in the Platonic dialogue. We must distinguish two phases of reception in the period under review. During the medieval phase, the main texts transmitting Pythagorean ${ }^{51}$ doctrine in technical detail are Boethius' De institutione arithmetica and De institutione musica, both of which are partially translations of the Greek theorist Nicomachus of Gerasa.

\subsection{Medieval Phase}

3.1.1 Berthold of Moosburg

Berthold of Moosburg knows his Pythagoreanism, in the first instance, through Boethius. In one passage he quotes from this source "Archytas the Pythagorean" (Archytas Pythagoricus) on the organization of the categories into a decadic

48 A little later, he says: "that same Mercury, whom Plotinus follows [...]" (Mercurius ipse quem Plotinus sequitur [...]), "Mercury [...] following him Plotinus [...]" (Mercurius [...] secutus hunc Plotinus [...]), etc.

49 Marsilio Ficino, Three Books on Life, eds C.V. Kaske, J.R. Clark (Tempe, Arizona: Arizona Center for Medieval and Renaissance Studies, 2002), lib. III, c. 26, p. 388, l. 77-p. 392, l. 139.

50 For more detail on this question, see S. Gersh, "Marsilio Ficino as Commentator on Plotinus. Some Case-Studies", in S. Gersh (ed.), Plotinus' Legacy. The Transformation of Platonism from the Renaissance to the Modern Era (Cambridge: Cambridge University Press, 2019), p. 19-43, at p. 36-41.

51 Many modern scholars distinguish between "Pythagorean" (=pre-Platonic) and "NeoPythagorean" (post-Platonic) doctrine - a distinction that we can ignore here as being meaningless for the authors presently under consideration. There are useful recent surveys in A. Hicks, "Pythagoras and Pythagoreanism in Late Antiquity and the Middle Ages", in C.A. Huffman (ed.), A History of Pythagoreanism (Cambridge: Cambridge University Press, 2014), p. 416-434; and M.J.B. Allen, "Pythagoras in the Early Renaissance", in Huffman (ed.), A History of Pythagoreanism, p. 435-453. 
structure, ${ }^{52}$ and in another the doctrine that all things derived from the primaeval nature are formed according to the principle of number. ${ }^{53}$ Secondly, Berthold's Pythagoreanism comes via Calcidius' Commentary on the Timaeus: for example, in a passage where he explicitly quotes this text as justification of the analogy between the division of multitude by the number 3 in arithmetic and the division of substance into indivisible, divided, and mixture in the Platonic account of the soul's generation. ${ }^{54}$

\subsubsection{Nicholas of Cusa}

The importance of Pythagoreanism for Nicholas of Cusa cannot better be documented than by citing the passage in the first book of De docta ignorantia which introduces a threefold arithmetical analogy comprising Unity, Equality, and Connection in order to express the trinitarian nature of the Absolute Maximum discussed earlier in the text. ${ }^{55}$ Although Nicholas refers to ancient Pythagoreanism, he is here clearly using one of his favourite medieval sources as an intermediary or at least as an inspiration, namely, the Boethian commentaries of Thierry of Chartres:

No nation has ever existed which did not worship God and believe that he was absolutely the Maximum. We find Marcus Varro in his books of Antiquities to have remarked that the Sisennii revered Unity as the Maximum, while Pythagoras - a man celebrated in his era for an irrefutable authority - further asserted that this Unity was a Trinity. In investigating its Truth and elevating our mind higher, let us argue according to the following premises: Nobody doubts that that which precedes all otherness is eternal, for otherness is the same as mutability. But everything that naturally precedes mutability is immutable and therefore eternal. Indeed, otherness consists of one thing and another, and so otherness

52 Berthold of Moosburg, Expositio super Elementationem theologicam Procli. Propositiones 14-34, eds L. Sturlese, M.R. Pagnoni-Sturlese, B. Mojsisch (Hamburg: Meiner, 1986), 24A, p. 126, l. 52-54, via Boethius, De institutione arithmetica, ed. G. Friedlein (Leipzig: Teubner, 1867 [photographic reprint Frankfurt a. M.: Minerva, 1966]), lib. II, c. 41, p. 139, l. 13-19.

53 Berthold of Moosburg, Expositio, 19A, p. 59, l. 40-45, via Boethius, De institutione arithmetica, lib. I, c. 2, p. 12, 1. 14-15. The passage in Berthold includes an intertextual crossreference to Proclus, De malorum subsistentia, ed. D. Isaac (Paris: Les Belles Lettres, 1982), c. $1, \S 4$, p. 33, l. $37-38$.

54 Berthold of Moosburg, Expositio, 6E, p. 131, 1. 162-17o. The reference is to Calcidius, In Timaeum, p. 27, 1. 6-14.

55 Nicholas of Cusa, De docta ignorantia, h I, lib. I, c. 7-9, p. 14, l. 22-p. 19, l. 14. Chapter 7 bears the heading: "On the trine and unitary Eternity" (De trina et una aeternitate). 
like number is posterior to Unity. Consequently, Unity is prior in nature to otherness and, since it precedes it naturally, is Eternal Unity. ${ }^{56}$

This passage is by no means alone in testifying to the importance of Pythagoreanism in Nicholas' thought. The precise metaphysical status of number is determined in his Idiota de mente ${ }^{57}$ where the character of the "Layman" praises the Pythagoreans for treating number not just mathematically as proceeding from our mind but "symbolically and rationally" (symbolice ac rationabiliter) as proceeding from the divine mind, the former number being the image of the latter ${ }^{58} \mathrm{He}$ adds that Pythagorean doctrine was followed by the Platonists who in their turn were followed by Boethius.

During the Renaissance phase, the aforementioned Latin texts transmitting Pythagorean doctrine in a technical sense were supplemented by numerous works becoming available for the first time in Greek. These included Plato's Timaeus and Parmenides together with their Greek commentaries by Proclus, Porphyry's De vita pythagorica, Iamblichus' De vita pythagorica and De communi mathematica scientia, Timaeus of Locri's De natura mundi et animae, and Hierocles' Commentaria in Aureum carmen.

\subsection{Renaissance Phase \\ 3.2.1 Marsilio Ficino}

Marsilio Ficino has an ambivalent view of Pythagoreanism. On the one hand, he emphasises the importance of Pythagoreanism within the tradition of "ancient theology" which always includes Pythagoras and sometimes also Philolaus as representatives of the Graeco-Italian school in the list of authorities. ${ }^{59}$ On the other hand, Ficino is highly critical of the doctrine

$5^{6}$ Nicholas of Cusa, De docta ignorantia, h I, lib. I, c. 7, p. 14, l. 24-p. 15, l. 10: Nulla umquam natio fuit quae Deum non coleret et quem maximum absolute non crederet. Reperimus $M$. Varronem in libris Antiquitatum annotasse Sissennios unitatem pro maximo adorasse. Pythagoras autem, vir suo aevo auctoritate irrefragabili clarissimus, unitatem illam trinam astruebat. Huius veritatem investigantes, altius ingenium elevantes dicamus iuxta praemissa: Id quod omnem alteritatem praecedit aeternum esse nemo dubitat. Alteritas namque idem est quod mutabilitas. Sed omne quod mutabilitatem naturaliter praecedit immutabile est, quare aeternum. Alteritas vero constat ex uno et altero; quare alteritas sicut numerus posterior est unitate. Unitas ergo prior natura est alteritate et, quoniam eam naturaliter praecedit, est unitas aeterna.

57 Nicholas of Cusa, Idiota de mente, h v, c. 6, §88, l. 11-22 and §95, l. 1-21.

58 See S. Toussaint, "Mystische Geometrie und Hermetismus in der Renaissance. Ficinus und Cusanus", in Perspektiven der Philosophie 26(2000), p. 339-356.

59 See the argumentum of the Pimander, cited above. Among later illustrations of this historical thesis see Ficino, In Ennead. I, proem 2. 
of transmigration of the soul into animals which he believes Plato to have endorsed only in a metaphorical sense, although some of the late ancient Platonici including Plotinus mistook it for a literal truth. ${ }^{60}$

During the period here under review, we must distinguish three phases in the interpretation of Plato based on the range of texts available: a medieval phase, a transitional phase, and a Renaissance phase. In the medieval phase, the main texts are Calcidius' translation and commentary on the Timaeus (as well as Cicero's translation), William of Moerbeke's translation of the Parmenides as lemmata within his translation of Proclus' commentary; ${ }^{61}$ Aristippus' translations of the Meno and Phaedo; ${ }^{62}$ and the doxographies in Augustine's Contra Academicos, De civitate Dei VIII, and De diversis quaestionibus, q. 46. The transitional phase utilizes the same texts together with certain newer humanist translations from the Greek. Among the latter are the Parmenides as a separate text translated by George of Trebizond in the fifteenth century, ${ }^{63}$ the Apology, Crito, and Phaedrus in the translation of Leonardo Bruni, ${ }^{64}$ and the Republic

6o See Marsilio Ficino, Commentary on Plotinus. Volume 4. Ennead III, Part 1, ed. S. Gersh (Cambridge, Mass.: Harvard University Press, 2017), In Ennead. III.4, §9-14. Cf. In Enneadem III.2, §30. In the Theologia platonica, Ficino proposes a classification of six Academies according to their tendency to read Plato's accounts of the vicissitudes of souls literally or metaphorically. See Marsilio Ficino, Platonic Theology. Volume 6. Books XVIIXVIII, eds M.J.B. Allen, J. Hankins (Cambridge, Mass.: Harvard University Press, 2006), lib. XVII, c. 1, §1-2, p. 6-8. See also Ficino, Theologia Platonica, lib. XVII, c. 3, §5, p. 32-34; Theologia Platonica, lib. XVII, c. 3, §10, p. 40-42; Theol. Plat., lib. XVII, c. 4, §1, p. 44-46.

61 See Proclus, Commentaire sur le Parménide de Platon, Traduction de Guillaume de Moerbeke, ed. C. Steel, 2 vols (Leuven / Leiden: Leuven University Press / Brill, 19821985), which includes Moerbeke's translation of extracts from Proclus' Commentary on the Timaeus (vol. 2, p. 559-587). Moerbeke's translation of the Parmenides is based on Proclus' lemmata and extends only as far as the "first hypothesis".

62 See Plato, Meno interprete Henrico Aristippo, eds V. Kordeuter, C. Labowsky (London: Warburg Institute, 1940) and Phaedo interprete Henrico Aristippo, ed. L. Minio-Paluello (London: Warburg Institute, 1950).

63 See J. Hankins, Plato in the Italian Renaissance, 2 vols (Leiden / New York: Brill, 1990), p. 180-186, 429-435; I. Ruocco (ed.), Il Platone latino. Il Parmenide. Giorgio di Trebisonda e il cardinale Cusano (Firenze: Olschki, 2003). George of Trebizond's translation - being independent of Proclus' commentary - covers the entire text of the Parmenides.

64 Fornotes on the provenance of the Apology, Crito, and Phaedrus translations and the preface to the Phaedrus see H. Baron (ed.), Leonardo Bruni Aretino. Humanistisch-philosophische Schriften, mit einer Chronologie seiner Werke und Briefe (Leipzig / Berlin: Teubner, 1928), p. 3-4, 172, and Hankins, Plato in the Italian Renaissance, p. 388-40o. For the Crito text 
in the translation of Pier Candido Decembrio. ${ }^{65}$ In the Renaissance phase, the main texts are the complete Latin translation of Plato by Ficino together with argumenta for all dialogues and longer commentaries on the Symposium (also called De amore), Phaedrus, Parmenides, Timaeus, and Philebus, and of course the Greek texts of Plato themselves. Among the many doctrinal aspects of this Plato reception, we will concentrate here on two that are particularly important for understanding the Platonists' own historical viewpoint: the notion of concealment and the relation between Plato and Aristotle.

\subsection{The Notion of Concealment}

The notion that the ancient Academy had pursued a deliberate strategy of concealing their metaphysical doctrine behind a display of sceptical methodology was very influential among later Platonists. The main authority for this teaching was Augustine, who in Contra Academicos lists the important teachings of Plato - the immortality of the human soul, the distinction between the intelligible and sensible worlds, and so forth - and reports that such doctrines were as much as possible "preserved and guarded as mysteries" (servata et pro mysteriis custodita) by his successors. According to Augustine, many students of philosophy were erroneously starting to believe that everything is corporeal, in response to which Arcesilaus "thoroughly concealed the doctrine of the Academy and buried it as a golden hoard to be discovered some day by posterity" ("occultasse penitus Academiae sententiam et quasi aurum inveniendum quandoque posteris obruisse"), preferring to disabuse those whom he considered badly taught rather than teach those whom he considered unteachable. ${ }^{6}$ The notion that Arcesilaus' adoption of sceptical methodology was a stratagem aimed at concealing dogmatic metaphysics seems to have been derived by Augustine from a rather oblique reading of a passage in Cicero's Academica in which the New Academic practice of arguing against all things and for all things "for the purpose of finding the truth" (veri inveniendicausa) is discussed. Here, Lucullus asks what these thinkers have discovered. The Academic replies that "their custom is not to show this" (non solemus [...] ostendere). Lucullus then asks what these "mysteries" (mysteria) are and why the school "conceals"

see Plato, Il Critone latino di Leonardo Bruni e di Rinuccio Aretino, eds E. Berti, A. Carosini (Firenze: Olschki, 1983).

65 See Hankins, Plato in the Italian Renaissance, vol. 1, p. 117-154.

66 Augustine, Contra Academicos, lib. III, c. 17, §37-c. $20, \S 45$ [at c. 17, §38]. It seems likely that Augustine understood the philosophical strategy of Arcesilaus as being broadly equivalent to Socrates', and therefore perhaps something that Socrates' follower Plato would himself have sanctioned. See Augustine, De civitate Dei, lib. viII, c. 4. 
(celare) these things as something base. The Academic replies that it is in order to guide our hearers by reason rather than by authority. ${ }^{67}$

In the opinion of certain medieval Platonists, this report by Augustine needed to be read in conjunction with a statement by Dionysius the Areopagite. In his ninth Letter, the latter explains that the theological tradition has a double aspect: on the one hand "the ineffable and the mysterious" (aporrhètos kai mustike) which is symbolic and employs initiation, and on the other hand "the manifest and more known" (emphanēs kai gnōrimōtera) which is philosophical and employs demonstration. Dionysius continues by explaining that symbolism has been utilized by the sacred writers both to protect the understanding of the highest truths from the multitude of the irreligious and to accommodate those understandings to the varying capacities of the hierarchy. ${ }^{68}$ It is worth noting immediately that Augustine and Dionysius have somewhat different ideas about what concealed and what was concealed within the philosophical thinking of their predecessors. With Augustine it was an autonomous dialectical methodology that concealed and Platonic metaphysics in general that was concealed, whereas with Dionysius it was symbolism and ritual that concealed and mystical unification that was concealed. The tension between the two approaches resulting from the intertextual use of these historical accounts will be the source of much that is both puzzling and productive in the later tradition.

\subsubsection{Berthold of Moosburg}

Berthold of Moosburg provides a good illustration of the reception and exploitation of the Augustinian thesis regarding Platonic concealment. In the Expositio tituli of his commentary, he attempts to contextualize Proclus' philosophical project by emphasising the crucial role of this philosopher in unwrapping the "coverings" (integumenta) with which the first Platonists, ${ }^{69}$ and especially the Academics, enwrapped their wisdom. He further explains that according to Cicero's account as relayed through Augustine, the custom of these thinkers was to "conceal" (occultare) their doctrine and not to "reveal" (aperire) it to anyone who had not spent an entire lifetime within their sect. ${ }^{70}$ According to Berthold, the Platonic wisdom that was kept concealed was a complete axiomatic system setting out the relation between the first cause and its many effects.

\footnotetext{
67 Cicero, Academica, lib. II, c. 18, §6o.

68 Dionysius, Epistula IX, §1, 1105D-1108B. Cf. Dionysius, De caelesti hierarchia, c. 2, §2, 140A-B and c. 2, §5, 145A-B; Dionysius, De ecclesiastica hierarchia, c. 1, §5, 377A.

69 Augustine had suggested, albeit rather tentatively, that it was Plotinus who accomplished this. See our discussion below.

70 Berthold of Moosburg, Expositio, Expos. tit. A, p. 37, l. 18-21.
} 


\subsubsection{Nicholas of Cusa}

Nicholas of Cusa supplies a striking example of the reception and exploitation of the corresponding Dionysian teaching together with a further refinement making it explicit that the Dionysian teaching is also a Platonic one. In one paragraph of De beryllo, he notes that both Plato "in his letters" (in epistulis) and great Dionysius forbade "these mysteries to be divulged" (haec mysteria [...] propalari) to those who do not know "the intellectual elevations" (elevationes intellectuales), ${ }^{71}$ and in another that Plato in his letters says that all things exist with the king of all things and for his sake and that he wrote wisely that this teaching should be held as a "secret" (secretum). ${ }^{72}$ The mystery to which Nicholas refers in both these passages is his own praxis of conjecture by which one is guided towards an experience of the first principle.

\subsubsection{Marsilio Ficino}

The notion of Platonic concealment has its most far-reaching implications in connection with Marsilio Ficino's doctrine of the "ancient theology" (prisca theologia). The fullest explanation of this can be found in the proem to his Commentary on Plotinus' Enneads where he makes the following main points. First, it was the custom of the ancient theological tradition from Hermes Trismegistus to Plato "to veil the divine mysteries both with mathematical numbers and figures and with poetic fictions" ("divina mysteria cum mathematicis numeris et figuris tum poeticis figmentis obtegere"). This was in order to prevent them from being rashly communicated to all and sundry. Second, Plotinus was the first and only thinker who stripped away these mathematical and poetic coverings from theology and "divinely penetrated into the secrets of the ancients" (arcana veterum divinitus penetravit). This statement is corroborated with the testimony of Porphyry and Proclus. ${ }^{73}$

In addition to making an extensive application to the historiography of philosophy, Ficino's rethinking of the notion of Platonic concealment - on which both the Augustinian and Dionysian formulations as well as scattered remarks in Proclus' writings were probably influential - is associated with several

71 Nicholas of Cusa, De beryllo, h XI/1, §2, l. 1-4. The references are to Plato, Epistula II, $312 \mathrm{~d}-\mathrm{e}$ (probably cited through Proclus, Théologie platonicienne. Livre II, eds H.-D. Saffrey, L.G. Westerink [Paris: Les Belles Lettres, 1974], lib. II. c. 8, p. 54, l. 24-25) and to Dionysius, Epistula IX, $\S 1,{ }_{105} \mathrm{D}$ - as cited above - and perhaps Dionysius, De mystica theologia, c. $1, \S 2,1000 \mathrm{~A}-\mathrm{B}$.

72 Nicholas of Cusa, De beryllo, h XI/1, §15, l. 1-§16, l. 19. The reference is to Plato, Epistola II, 312e-313a (probably cited through Proclus, Theologia platonica, lib. II, c. 8-9, p. 51, l. 21-p. 61, l. 9).

73 Marsilio Ficino, In Enneadem I, pr. §2, ed. S. Gersh. 
striking new developments resulting from the availability of the complete Platonic corpus. These include a hermeneutical distinction that seems to have been conceived specifically in order to maintain that the ancient Athenian did not himself believe literally in transmigration, although the distinction itself also has more general philosophical implications. In Platonic Theology XVII, Ficino argues that Plato affirms as literally true regarding divine matters only what is stated in those of his writings where he speaks in his own person, whereas the statements regarding similar topics contained in his other dialogues where he is reporting the views of the ancients should be understood in a non-literal manner. ${ }^{74}$ In the course of this same discussion, the Florentine also shows how this thesis is useful in explaining the seemingly enigmatic statements of Plato in his Second and Seventh Letters that no written work of his has existed or ever will exist on divine matters and therefore that nobody has existed or will exist who will understand his views on such questions. ${ }^{75}$ According to Ficino, the teachings of Plato regarding the existence of divine providence and the immortality of the soul are disclosed in such texts as the Letters and the Laws where the author speaks in his own person, whereas his views on other matters are mysteries veiled in the manner of the ancient theologians and presented as the utterances of such literary characters as Timaeus, Parmenides, and Melissus.

Ficino's rethinking of the notion of Platonic concealment also includes a further hermeneutical distinction that is useful for maintaining that the ancient Athenian did not advocate the doctrine of transmigration in a literal sense. Also in Platonic Theology XVII, the Florentine argues that the concealment of doctrine by the earliest Academy led to a variety of interpretations of the ancient theology on the part of later thinkers that can be associated with six "academies" following one another in a sequence of which the first three were Greek and the second three foreign. ${ }^{76}$ These schools were: the "old" academy headed by Xenocrates, the "middle" academy under the headship of Arcesilaus, and the "new" academy headed by Carneades, followed by the

74 Marsilio Ficino, Theologia Platonica, lib. XVII, c. 4, §6, p. $5^{2}$ and lib. XVII, c. 4, §14, p. 6o-62.

75 Marsilio Ficino, Theologia Platonica, lib. XVII, c. $4, \S 5-6$, p. 50-52 - the references are to Plato, Epistola II, 314c and Epistola VII, 341c. Cf. Ficino's Argumentum in Epistulam II, Opera omnia, p. 1530-1532 and Argumentum in Epistulam VII, Opera omnia, p. 1534-1535.

76 Marsilio Ficino, Theologia Platonica, lib. XVII, c. 1, §2, p. 6-8. The symmetry with the set of six ancient theologians is obvious and deliberate on Ficino's part. For him, the entire history of philosophy is governed by divine providence which proceeds in an orderly - and hence, numerical - manner. On Ficino's history of the six academies see Hankins, Plato in the Italian Renaissance, vol. 1, p. 283, notes 41-42, and M.J.B. Allen, Synoptic Art. Marsilio Ficino on the History of Platonic Interpretation (Firenze: Olschki, 1998), p. 56-79. 
"Egyptian" academy headed by Ammonius, ${ }^{77}$ the "Roman" academy under the headship of Plotinus, and the "Lycian" academy headed by Proclus. Ficino is highly critical of the last two Academies with respect to their interpretation of the circulation of souls in a literal sense, ${ }^{78}$ whereas he endorses the view of the first four Academies and especially the first and fourth which take a more metaphorical approach to the same doctrine. ${ }^{79}$ It is not clear to what extent the Florentine would maintain precisely this classification when considering the history of Platonic tenets other than that of transmigration, especially given the rather artificial distinction between the school of Ammonius and that of Plotinus and the placing of the normally "divine" Plotinus in the less favoured camp.

\subsection{The Relation between Plato and Aristotle}

In Contra Academicos, Augustine speaks of a certain doctrine of the truest philosophy as having been consolidated through many centuries by industrious and discerning men who continued to teach that "Aristotle and Plato are so concordant with one another that it is to the unskilled and inattentive that they seem to disagree" ("Aristotelem et Platonem ita sibi concinere ut imperitis minusque attentis dissentire videantur"). ${ }^{80}$ This statement is clearly based on Cicero who reports in his Academica - in his turn, explicitly quoting Varro - that originating with Plato there was established a philosophy that was "single and harmonious" (una et consentiens), despite having the two names of "Academic" and "Peripatetic". Both schools in dependence on Plato produced "a certain science of philosophy, an ordering of subject-matter, and a system of teaching" ("ars quaedam philosophiae et rerum ordo et descriptio disciplinae"): something inconsistent with the Socratic manner of discussing everything in a doubting manner. Although there was originally "no difference between the Peripatetics and that Old Academy" ("nihil [...] inter Peripateticos et illam veterem Academiam differe") and both drew from the same source, ${ }^{81}$ Aristotle excelled in a certain abundance of ingenuity. ${ }^{82}$ Now, Augustine's statement somewhat transforms the original account on which it depends for, whereas Cicero views the concordance between Plato and Aristotle as vested in the systematization of thinking and accords a certain primacy to Aristotle,

\footnotetext{
$77 \quad$ I.e. Ammonius Saccas.

78 Marsilio Ficino, Theologia Platonica, lib. XVII, c. 3, p. 28-44.

79 Marsilio Ficino, Theologia Platonica, lib. XVII, c. 4, p. 44-62.

8o Augustine, Contra Academicos, lib. III, c. 19, §42.

$81 \quad$ I.e. Plato.

82 Cicero, Academica, lib. I, c. 4, §17. Cf. Cicero, Academica, lib. II, c. 5, §15 for a briefer statement.
} 
the continuation of Augustine's text associates the concordance with the doctrine of the intelligible and sensible worlds and implicitly prioritises Plato.

These reports concerning the original concordance between Platonic and Aristotelian thought were well known to the medieval and Renaissance Platonists who understood them in connection with the synthesising approach to the two traditional doctrines that they observed in the Latin Platonic writings of late antiquity in general. For them, there were clearly many possible answers to the question of precisely how a doctrinal concordance that is obviously not intended to be a purely nominal distinction must be understood, and the type of solutions envisaged clearly varied in accordance with information regarding the content of Plato's and Aristotle's writings gradually emerging between the twelfth and the fifteenth centuries. However, the concordance between Platonic and Aristotelian thought as understood by the authors studied in this essay undoubtedly took the form of a complex network of identities and differences between various philosophical tenets in which the balance was in effect always tilted towards the Platonic side of the equation.

\subsubsection{Berthold of Moosburg}

The radically Platonic character of the Elementatio theologica of Proclus, the sole work on which Berthold of Moosburg is commenting, would seem to militate against any commitment on his part to the traditional doctrine of concordance. Nevertheless, much of the Elementatio's philosophical procedure had already integrated Aristotelian notions and - to take the most immediately obvious example - Berthold furthers this approach by expressing the propositional method itself in the technical terminology of the four causes. ${ }^{83}$ Thus, the Platonic author corresponds to the efficient cause of the Elementatio, ${ }^{84}$ the prior definitions represent its material cause, ${ }^{85}$ the network of implications and exclusions of propositions, the application of common notions, and the necessity inherent in the whole system correspond to its formal cause, ${ }^{86}$ and the arrangement of propositions in a sequence representing scalar ascent to the first principle represent its final cause. ${ }^{87}$ Although the introduction of the four causes in this manner illustrates a common procedure with the accessus ("introductions") to philosophical works adopted by scholastic writers, and although the establishment of analogies between literary and metaphysical

83 Berthold of Moosburg, Expositio, Expos. tit., p. 37, 1. 5-9.

84 Berthold of Moosburg, Expositio, Expos. tit., p. 37, l. 7 and l. 10-14.

85 Berthold of Moosburg, Expositio, Expos. tit. I, p. 45, l. 296-p. 46, l. 313.

86 Berthold of Moosburg, Expositio, Expos. tit. K, p. 47, l. 343-p. 49, l. 407.

87 Berthold of Moosburg, Expositio, Expos. tit. L, p. 49, l. 408-414 and $420 \mathrm{off}$. 
structures is not foreign to ancient Neoplatonism, there is absolutely nothing in the original Greek text of Proclus or its Latin translation that suggests precisely this organisation.

But when turning from methodology to content, we do find Berthold more inclined to argue that Plato and Aristotle "are divergent and not in harmony" (diversantur [...] non concordant). ${ }^{88}$ Maintenance of the distinction between the two thinkers is especially marked in the section called Praeambulum in the course of which the commentator explains the nature of Proclus' philosophy by setting up a series of metaphysical contrasts between the two more ancient authorities. Here, he notes with respect to the object of highest intellectual activity, that this is "being qua being" (ens in eo quod ens) for Aristotle but the One or Good for Plato; ${ }^{89}$ with respect to the psychic faculty to be employed in this activity, that this is the "intellect" (intellectus) for Aristotle but "a knowing above intellect" (cognitio supra intellectum) for Plato; ${ }^{90}$ and with respect to the name of the process, that this is "metaphysics or first philosophy" (metaphysica / prima philosophia) for Aristotle but "divine super-wisdom" (divinalis supersapientia) for Plato. ${ }^{91}$ It is perhaps obvious from this summary that the "Plato" to which Berthold here refers has much more in common with Dionysius the Areopagite than with the founder of the Academy.

\subsubsection{Nicholas of Cusa}

Nicholas of Cusa follows the Augustinian tradition in according Platonism a privileged status on the grounds of its unique affinity with Christianity, at the same time reflecting a pattern widespread among earlier medieval thinkers of seeing "Platonism" as broadly identifiable with the theology of Dionysius the Areopagite.$^{92}$ On occasion, we do find him explicitly contrasting Plato favourably with Aristotle: for instance, when considering the question of the world's eternity or createdness in Devenatione sapientiae, he notes that Aristotle denies

88 Berthold of Moosburg, Expositio, Praeambulum C, p. 65, 1. 430-432.

89 Berthold of Moosburg, Expositio, Praeamb. B, p. 56, l. 116-119, and Praeamb. C, p. 65, l. 422429. Cf. Berthold of Moosburg, Expositio, 1A, p. 74, l. 113-123.

90 Berthold of Moosburg, Expositio, Praeamb. C, p. 65, l. 433-p. 66, l. 458, and p. 67, l. 504-p. 68, l. $5^{28}$.

91 Berthold of Moosburg, Expositio, Praeamb. C, p. 65, l. 422-p. 66, l. 458, and p. 68, l. 539-540.

92 For evidence regarding Nicholas' understanding of Plato and the Platonic Tradition see M.L. Führer, "Cusanus Platonicus. References to the Term Platonici in Nicholas of Cusa", in S. Gersh, M.J.F.M. Hoenen (eds), The Platonic Tradition in the Middle Ages. A Doxographic Approach (Berlin / New York: De Gruyter, 2002), p. 345-370; and S. Gersh, "The Virtue of Absence. Nicholas of Cusa and the Historical Plato", in A. Balansard, I. Koch (eds), Lire les dialogues, mais lesquels et dans quel ordre? Définitions du corpus et interprétations de Platon (Sankt Augustin: Academia, 2013), p. 117-131. 
that the "possibility of coming-to-be" (posse fieri) has a beginning, whereas Plato "with superior vision" (melius videns) said that time is the image of the eternal. ${ }^{93}$ However, these passages are surprisingly rare for such a committed Platonist as Nicholas, and he more frequently endeavours to read Aristotle in the most charitable way, often by reporting his doctrine in an already platonised form via Albert the Great or various Arabic commentators. His ultimate position is that stated in the formal debate between a Peripatetic "philosopher" and a Platonic-Dionysian "layman" entitled Idiota de mente: namely, that the relation between the viewpoints characterised here as Aristotelian and Platonic must itself be understood in terms of the coincidence of opposites. ${ }^{94}$

Notable examples of his obliquely affirmative characterisations of Aristotle and the Peripatetics can be found in works from Nicholas' middle to late periods. In De non-aliud, he remarks that although the Stagirite "fell short" (defecerit) in first or mental philosophy, he nevertheless wrote many completely praiseworthy things in the rational and moral spheres. ${ }^{95}$ In De apice theoriae, Nicholas states rather cryptically that the "mental power" (posse mentis) of Aristotle is displayed only partially in his books, and that this fact is something that the ignorant "do not see" (non vident) ${ }^{96}$ What Nicholas is saying here is that the real posse of Aristotelian thought - this technical term signifying both its "power" and its "possibilities" - is only disclosed by skilful interpretation the "seeing" also mentioned and equated with the interpreter's intellectual elevation. Presumably, an instance of reading Aristotle in the right manner would be Nicholas' own explanation in De beryllo ${ }^{97}$ and De venatione sapientiae $^{98}$ of the Stagirite's notion of intellect as being both a triunity and a multiplicity of forms. A further example would be his refashioning in De nonaliud of Aristotle's question whether or not one and being are other than the

93 Nicholas of Cusa, De venatione sapientiae, h XII, c. 9, §25, l. 1-§26, l. 4. There is one other major issue concerning which Nicholas prefers Platonism to Aristotelianism: namely, the status of the law of contradiction. This point will be discussed below in connection with axiomatics.

94 Nicholas of Cusa, Idiota de mente, h v, c. 2, §66, l. 19-§67, l. 3; c. 3, §71, l. 1-2; and c. 4, §77, 1. 15-26. On Nicholas' Aristotelianism see S. Gersh, "Medieval Platonic Theology. Nicholas of Cusa as Summation and Singularity", in J. Hankins, F. Meroi (eds), The Rebirth of Platonic Theology. Proceedings of a Conference held at The Harvard University Centre for Italian Renaissance Studies (Villa I Tatti) and the Istituto Nazionale di Studi sul Rinascimento (Firenze, 26-27 April, 2007) (Firenze: Olschki, 2013), p. 15-45, at p. 30-35.

96 Nicholas of Cusa, De apice theoriae, h XII, §21, l. 1-§22, l. 6.

97 Nicholas of Cusa, De beryllo, h XI/1, §36, l. 8-15; §39, l. 5-8.

98 Nicholas of Cusa, De venatione sapientiae, h XII, c. 8, §22, l. 1-§24, l. 22. Cf. De non-aliud, h XIII, c. 10, p. 22, l. 23-p. 23, l. 9. 
substance of beings as an answer to the effect that they are the "not-other" (non aliud). ${ }^{99}$

In actual fact, it is because of his rather ingenious reading of Aristotle that Nicholas is able ultimately to subscribe to the traditional ancient and medieval notion of the concordance of Platonism and Aristotelianism. It is likewise because of a particular reading of "Plato" that avoids the caricature of "Platonism" as amounting to the identification of logical genera and species with separate substances: a view that is explicitly rejected in De beryllo. 100 The Platonism that Nicholas espouses is always rather the version implicit in Dionysius the Areopagite's writings on which various teachings of nonChristian Platonists such as Proclus can sometimes be treated as commentary. This can be seen in Idiota de mente where the Layman explains that according to the Aristotelian doctrine, the contents of sensation form the basis of the contents of reason and the contents of reason form the basis of the contents of intellect. But according to the Platonic doctrine, the contents of sensation form the basis of the contents of reason whereas the contents of reason do not form the basis of the contents of intellect. The Layman finally concludes that according to the combined Platonic and Aristotelian doctrine, the contents of sensation form the basis of the contents of reason, while reason by turning first towards sensation and then towards intellect cognitively multiplies the first principle's single infinite Form. ${ }^{101}$

\subsubsection{Marsilio Ficino}

A commitment to the traditional doctrine of concordance was relatively easy for Marsilio Ficino to make. ${ }^{102}$ When Ficino's attention had shifted from Proclus to Plotinus, ${ }^{103}$ he could rely on the testimony of the latter's biographer Porphyry that concealed Stoic and Peripatetic doctrines were blended into his teacher's writings, that Aristotle's metaphysical doctrines were concentrated in them, and that Peripatetic commentaries were read in Plotinus'

99 Nicholas of Cusa, De non-aliud, h XIII, c. 18-19, p. 44, l. 1-p. 47, l. 14. Cf. De venatione sapientiae, h XII, c. 21, §6o, l. 1-12.

100 Nicholas of Cusa, De beryllo, h xI/1, §49, l. 9-17.

101 Nicholas of Cusa, Idiota de mente, h v, c. 2, §65, l. 1-§66, l. 20; and c. 4, §77, l. 1-§79, l. 10. For the first point see especially Idiota de mente, h v, c. 2, §63, l. 1-\$66, l. 20. For the second point see Idiota de mente, h v, c. 2, §67, l. 1-§68, l. 16; c. 3, §71, l. 1-9; c. 4, §74, l. 1-§79, l. 10; and c. 7, §99, l. 1-§107, l. 14. For the first point see also De docta ignorantia, h I, lib. II, c. 6, p. 8 o, l. 1-p. $81,1.15$.

102 On the possibility of an evolution in Ficino's thinking on this point see J. Monfasani, "Marsilio Ficino and the Plato-Aristotle Controversy", in M.J.B. Allen, V. Rees (eds), Marsilio Ficino. His Theology, his Philosophy, his Legacy (Leiden: Brill, 2002), p. 179-202.

103 See below. 
seminarsincluding those of Aspasius, Alexander of Aphrodisias, and Adrastus. ${ }^{104}$ Indeed, Porphyry was himself one of the earliest proponents of the doctrine of concordance and perhaps one of the influences behind Augustine's endorsement of the thesis. When the Florentine comes to write a formal commentary on Plotinus, he declares that his own aims as an exegete are to explain here not only how Plotinus reveals the hidden meaning of Plato's utterances but also how Plotinus provides us with a correct interpretation of Aristotle. ${ }^{105}$ This same commentary is indeed very informative concerning certain major points at which Ficino finds the two ancient thinkers in agreement, ${ }^{106}$ other points at which he considers them to be divergent, ${ }^{107}$ and still other points at which he finds their relation to be ambivalent. ${ }^{108}$

For Ficino, the real dispute was not between Plato and Aristotle but between the better commentators of Aristotle - those including Plotinus who emphasise Aristotle's "Platonism" - and worse commentators - those who concentrate on the differences between the two ancient thinkers. In one important passage, the Florentine goes as far as to argue that Plotinus himself can be seen as resolving the conflict between those Peripatetics who follow Alexander in thinking that the human intellect is individual but mortal and those who follow Averroes in maintaining that it is immortal but not individual. According to Ficino, if the reader accepts, on the one hand, the multiplicity of individual human intellects with Alexander and, on the other, the immortal gift of total intelligence with Averroes, he will come into possession of "the complete doctrine of our Plotinus" (integra Plotini nostri sententia). ${ }^{109}$ Ficino has touched

\footnotetext{
104 Porphyry, Vita Plotini, §14. Cf. Ficino's translation, Opera omnia, p. 1542.

105 Marsilio Ficino, In Enneadem I, pr., §2-3.

106 See Marsilio Ficino, In Enneadem I.1, §19. With respect to a discussion of the relation between discursive reason and intellect, Ficino concludes that Plotinus "in employing here the terminology of Aristotle, indicates that Aristotle in this context differs hardly at all from Plato" (dum vero hic verbis Aristotelis utitur, significat Aristotelem in his a Platone minime dissidere).

107 See Marsilio Ficino, In Enneadem I.3, §15. Concerning the subject of metaphysics, Ficino notes that Plato deals with being endowed with a self-sufficient condition of relatedness to that which is superior and that which is inferior to being - i.e. in the Parmenides -, whereas Aristotle is concerned with being qua being subsumed under the notion of being which is common to all things - i.e. in the Metaphysics.

108 See Marsilio Ficino, In Enneadem I.4, §35. With respect to the doctrine of mind, Ficino concludes that Aristotle in De anima III maintains that intellect truly exists as immortal but in other places denies that there is remembrance - and therefore a rational power after death.

109 Marsilio Ficino, In Enneadem I.1, §15-16.
} 
upon this question earlier in the commentary while reformulating it as a conflict between those who think with Alexander that intellect can be the proper life of the body and those who think with Averroes that intellect cannot properly give life to the body. ${ }^{110}$

\section{Latin Platonists}

Any attempt to situate the three subjects of the present study in terms of their consciousness of themselves within a historical tradition must also take account of an influential group of late ancient Latin writers of philosophical or semi-philosophical character. These writers continued to be studied by all the medieval Platonists primarily because they preserved important remnants of the precious ancient Greek philosophy lost to readers in the Latin-speaking west since the fifth century. We must distinguish two phases of their reception in the period under review. During the medieval phase, Calcidius' Commentarius in Timaeum, Macrobius' Commentarius in Somnium Scipionis, Martianus Capella's De nuptiis Philologiae et Mercurii, and Boethius' De consolatione philosophiae were the most important texts.111

\subsection{Medieval Phase}

\subsubsection{Berthold of Moosburg}

Berthold of Moosburg provides an elegant example of intertextual reading when he explains that the theta and $p i$ and the steps placed between these letters embroidered on Philosophia's robe according to Boethius' De consolatione philosophiae represent stages in the ascent to the first principle through the propositional method set out in Proclus' Elementatio theologica. ${ }^{112}$ Not less striking is Berthold's application of Proverbs 9:1 on Wisdom as having built her house by cutting out seven columns to the seven primordial causes of Eriugena and the Clavis physicae and their various participations through the

\footnotetext{
110 Marsilio Ficino, In Enneadem I.1, §8.

111 For discussion of these authors and works in general see S. Gersh, Middle Platonism and Neoplatonism. The Latin Tradition, 2 vols (Notre Dame, Ind.: University of Notre Dame Press, 1986); and for specific examples of their medieval transmission, S. Gersh, "The First Principles of Latin Neoplatonism. Augustine, Macrobius, Boethius", in Vivarium 5o(2012), p. 113-138.

112 Berthold of Moosburg, Expositio, Expos. tit. L, p. 49, l. 415-p. 51, l. 491. The reference is to Boethius, De cons. philos., lib. I, pr. 1, §3-4.
} 
interpretation of the number 7 and its factors $(1+6,2+5,3+4)$ in Macrobius' Commentarius in Somnium Scipionis. ${ }^{113}$

\subsubsection{Nicholas of Cusa}

That these Latin Platonists of antiquity continue to have an impact on Nicholas of Cusa is shown by a passage in his De docta ignorantia, ${ }^{114}$ which forms a link between the earlier discussion of the Absolute Maximum as Unity, Equality, and Connection, ${ }^{115}$ and the later one of the process through which we receive "guidance" (manuductio) towards that Absolute through a series of geometrical examples. ${ }^{116}$ Here, Nicholas is referring directly to a passage in Martianus Capella's De nuptiis Philologiae Mercurii describing the ritual of purgation in which the allegorical figure of Philology prepares for deification. ${ }^{117}$

Let us now inquire what Martianus means when he says that Philosophia, desiring to ascend to the knowledge of this Trinity, vomited circles and spheres. It has previously been shown that there is only a single and most simple Maximum, and that neither the most perfect solid figure - the sphere - nor the most perfect plane figure - the circle - nor the most perfect rectilinear figure - the triangle - nor the figure of the simplest rectilinearity - the straight line - is such a Maximum. This Maximum is above all these things to such an extent that we must necessarily expel everything that is attained through sense, imagination, or reason together with their material associations in order to reach that most simple and most abstract understanding where all things are one, and where the line is a triangle, a circle, and a sphere. ${ }^{118}$

113 Berthold of Moosburg, Expositio, Prol. 11, p. 19, l. 451-471. The reference is to Macrobius, Commentarius in Somnium Scipionis, ed. J. Willis (Leipzig: Teubner, 1970), lib. I, c. 6, p. 19, l. $16 \mathrm{ff}$. On Berthold's study of Macrobius see I. Caiazzo, "Mains célèbres dans les marges des Commentarii in Somnium Scipionis de Macrobe", in D. Jacquart, C. Burnett (eds), Scientia in margine. Études sur les marginalia dans les manuscrits scientifiques du Moyen Âge à la Renaissance (Genève: Librairie Droz, 2005), p. 171-189.

114 Nicholas of Cusa, De docta ignorantia, h I, lib. I. c. 10, p. 19, l. 18-20.

115 Nicholas of Cusa, De docta ignorantia, h I, lib. I. c. 5-9, p. 11, l. 23-p. 19, l. 14.

116 Nicholas of Cusa, De docta ignorantia, h I, lib. I, c. 10, p. 19, l. $15 \mathrm{ff}$.

117 Martianus Capella, De nuptiis Philologiae et Mercurii, ed. J. Willis (Leipzig: Teubner, 1983), lib. II, §135-138, p. 42, l. 5-p. 43, l. 6.

118 Nicholas of Cusa, De docta ignorantia, h I, lib. I, c. 10, p. 19, l. 18-p. 20, l. 9: Nunc inquiramus quid sibi velit Martianus quando ait Philosophiam ad huius trinitatis notitiam ascendere volentem circulos et sphaeras evomuisse. Ostensum est in prioribus unicum simplicissimum maximum, et quod ipsum tale non sit nec perfectissima figura corporalis, ut est sphaera, aut superficialis, ut est circulus, aut rectilinealis, ut est triangulus, aut simplicis rectitudinis, ut est linea. Sed ipsum super omnia illa est, ita quod illa quae aut per sensum aut 
According to the well-known earlier medieval exegesis of this text by Remigius of Auxerre, the cognitive ascent of the human soul signified by Philologia's purgation involves the setting aside of the contents of the medieval quadrivium in order to reach a transcendent unknown. ${ }^{119}$ Nicholas has considerably enriched the metaphysical significance of the original. For him, this ascent especially includes the transition from an understanding of finite geometrical figures in their discreteness to the comprehension of infinite ones coinciding in the Absolute Maximum.

During the Renaissance phase, the aforementioned Latin texts were gradually superseded as sources of ancient philosophical doctrine by the original Greek writings, even if they continued to be admired for their imaginative qualities. However, Calcidius' Commentarius in Timaeum and Boethius' mathematical writings at least were of sufficiently technical character to retain their position in the curriculum alongside the newly acquired treatises.

\subsection{Renaissance Phase \\ 5.2.1 Marsilio Ficino}

Ficino's earliest studies on Platonism were based on the Latin sources mentioned and as late as 1489 he continues to recommend as sources of Platonic study: Boethii Consolatio [...], Calcidii commentarium in Timaeum, Macrobii expositio in Somnium Scipionis and other Latin writings. ${ }^{120}$ His own practice is to refer quite often to Boethius' De consolatione philosophiae: notably, in emphasizing the predominance of the subjective aspect in epistemology $y^{121}$ and in establishing doctrinal equivalence between Boethius and Proclus, ${ }^{122}$ and also less often to quote Calcidius' In Timaeum: for instance, in connection

imaginationem aut rationem cum materialibus appendiciis attinguntur necessario evomere oporteat ut ad simplicissimam et abstractissimam intelligentiam perveniamus ubi omnia sunt unum, ubi linea sit triangulus circulus et sphaera.

119 Cf. Remigius of Auxerre, Commentum in Martianum Capellam, ed. C.E. Lutz, 2 vols (Leiden: Brill, 1962-1965), vol. 1, lib. II, lemma 59, l. 6, p. 173-174. This commentary was widely used throughout the Middle Ages.

120 Marsilio Ficino, Epistulae, lib. IX, 12, Opera omnia, p. 899.

121 Marsilio Ficino, Commentary on Plotinus. Volume 5. Ennead III, Part 2, and Ennead IV, ed. S. Gersh (Cambridge, Mass.: Harvard University Press, 2018), Iv.6, §1 - reference to Boethius, De consolatione philosophiae, lib. v, m. 4, §1-9.

122 Marsilio Ficino, Commentaries on Plato. Volume 2. Parmenides, Part 1, ed. M. Vanhaelen (Cambridge, Mass.: Harvard University Press, 2012), c. 32, p. 128 - reference to Boethius, De consolatione philosophiae, lib. v, pr. 4, l. 70-116 -; Marsilio Ficino, Commentaries on Plato. Volume 2. Parmenides, Part 2, ed. M. Vanhaelen (Cambridge, Mass.: Harvard University Press, 2012), c. 97, p. 266 - reference to De consolatione philosophiae, lib. III, m. 9, l. 15-17. 
with the structure of means ${ }^{123}$ and the mechanism of sight. ${ }^{124}$ Ficino's continued use of Boethius was no doubt influenced by Boethius' status as a Christian Platonic authority and Calcidius' as a writer of mathematical sophistication. ${ }^{125}$

\section{$6 \quad$ Proclus}

During the period here under review, we can distinguish three phases in the interpretation of Proclus based on the range of texts available: a Medieval phase, a transitional phase, and a Renaissance phase. ${ }^{126}$ In the medieval phase, the main texts are the Elementatio theologica, Elementatio physica, Tria opuscula, and Commentarius in Parmenidem, in translations by William of Moerbeke. ${ }^{127}$ These texts are all used by Berthold who as a pioneer - and obviously in contrast to his usage of the Hermetica where scholastic doxographies sometimes intervene - always cites them directly through their Latin translations.

\subsection{Berthold of Moosburg}

We will confine ourselves to making just a few illustrations of Berthold's extensive intertextual handling of the Athenian scholarch. In the course of his exposition, the first explicit citation of Proclus' Elementatio physica occurs when Berthold explains the key term elementatio itself with reference to a work on physics "which this same author is also said to have published" ("quam etiam iste auctor dicitur edidisse"). ${ }^{128}$ Turning to the Tria opuscula, we find very extensive use in connection with numerous central theological doctrines, especially

123 Marsilio Ficino, Compendium in Timaeum, Opera omnia, c. 19, p. 1446 - reference to Calcidius, In Timaeum, §8-22, p. 61, l. 10-p. 73, l. 4.

124 Marsilio Ficino, Compendium in Timaeum, Opera omnia, c. 41 (= c. 42 [correcting defective pagination]), p. 1446 - reference to Calcidius, In Timaeum, §236-48, p. 248, 1. 15-p. 259, l. 17 .

125 Ficino also continues to use Macrobius' Commentarius in Somnium Scipionis - mostly without explicit citation - as a source of the "Platonists"' doctrines regarding cosmic harmony and the souls' celestial journeys. Cf. Marsilio Ficino, Theol. plat, lib. XVIII, passim. On Ficino and Macrobius see Caiazzo, "Mains célèbres".

126 For a survey of Proclus' influence during the Middle Ages see S. Gersh, "One Thousand Years of Proclus. An Introduction to his Reception”, in S. Gersh (ed.), Interpreting Proclus. From Antiquity to the Renaissance (Cambridge: Cambridge University Press, 2014), p. 1-29.

127 See Proclus, Elementatio theologica, translata a Guillelmo de Moerbeke, ed. H. Boese (Leuven: Leuven University Press, 1987) and Proclus, Commentaire sur le Parménide de Platon, Traduction de Guillaume de Moerbeke.

128 Berthold of Moosburg, Expositio, Expos. tit. I, p. 45, l. 280-284. 
in such a manner as to facilitate the establishment of doctrinal connections between Proclus and Dionysius the Areopagite. In fact, the editors of vol. 1 (Propositions 1-13) of the Expositio list four passages of De $X$ dubitationibus circa providentiam, nine passages from De malorum subsistentia, and eight passages from De providentia et fato that are cited often repeatedly within that part of the Expositio alone. Finally, there is a rare citation of Proclus' Commentarius in Parmenidem in the course of Berthold's exposition when he quotes "according to Proclus On the Parmenides" (secundum Proclum Super Parmenidem) a statement to the effect that the world is the plenitude of all kinds of forms. ${ }^{129}$

In the transitional phase, the main texts are the four translations by William of Moerbeke mentioned above together with an important new translation that appears in the intellectual milieu surrounding Nicholas of Cusa. ${ }^{130}$

\subsection{Nicholas of Cusa}

It is from the time of his De beryllo (1458) onwards that Nicholas of Cusa, having earlier relied on Platonic material derived through the Latin tradition as supplemented by Moerbeke's work, began to turn to Greek works in newer humanistic translations. ${ }^{131}$ Most important among the latter was the Theologia Platonis of Proclus as translated by Pietro Balbi of which important manuscripts survive containing Nicholas' own marginalia. ${ }^{132}$ Nicholas' enthusiastic

129 Berthold of Moosburg, Expositio, Prol. 11, p. 17, l. 4O1-4O2.

130 Nicholas of Cusa's encounter with Proclus and especially his glossing of the Moerbeke translations is discussed by S. Gersh, "Nicholas of Cusa", in S. Gersh (ed.), Interpreting Proclus. From Antiquity to the Renaissance, p. 318-349. On more specific philosophical questions see W. Beierwaltes, "Cusanus und Proklos. Zum neuplatonischen Ursprung des non-aliud", in Nicolò Cusano agli inizi del mondo moderno. Atti del Congresso internazionale in occasione del V centenario della morte di Nicolò Cusano, Bressanone 6-10 settembre 1964 (Firenze:Sansoni, 1970), p.137-140;W. Beierwaltes, "Das seiende Eine.Zur neuplatonischen Interpretation der zweiten Hypothesis des platonischen Parmenides. Das Beispiel Cusanus", in G. Boss, G. Seel (eds), Proclus et son influence. Actes du Colloque de Neuchâtel, juin 1985 (Zürich: Éditions du Grand Midi, 1987), p. 287-297; W. Beierwaltes, "Centrum tocius vite. Zur Bedeutung von Proklos' Theologia Platonis im Denken des Cusanus”, in A.-Ph. Segonds, C. Steel (eds), Proclus et la Théologie platonicienne. Actes du Colloque international de Louvain, 13-16 mai 1998, en l'honneur de H.-D. Saffrey et L.G. Westerink (Leuven / Paris: Leuven University Press / Brill, 2000), p. 629-651; and Gersh, "Medieval Platonic Theology", p. 15-45.

131 There are also some traces of influence from this material in earlier works - especially $D e$ coniecturis - although the main development is after De docta ignorantia and mostly late. See R. Haubst, "Die Thomas- und Proklos-Exzerpte des 'Nicolaus Treverensis' in Codicillus Strassburg 84", in Mitteilungen und Forschungsbeiträge der Cusanus-Gesellschaft 1(1961), p. $17-51$.

132 Marginalia on Proclus' Elementatio theologica also survive although, for reasons that we cannot pursue here, these are much less detailed. For the texts of the marginalia see 
use of his new sources is indicated in dramatic form at the beginning of $D e$ non-aliud where the character of the Abbot is said to have been busy in the study of Proclus' In Parmenidem and that of Peter to be currently in the process of translating Proclus' Theologia Platonis. ${ }^{133}$ Further evidence is provided by De venatione sapientiae where Nicholas refers to Proclus' Theologia Platonis by its Latin title and states that it contains six books, ${ }^{134}$ and where there are numerous verifiable citations both of the In Parmenidem and of the Theologia Platonis. ${ }^{135}$

In the Renaissance phase, the main texts are the four translations by William of Moerbeke once again, Balbi's translation of the Theologia Platonis, together with the Greek texts of Proclus' writings that were brought into prominence by Ficino's translations and commentaries. ${ }^{136}$

\subsection{Marsilio Ficino}

It can be assumed that Ficino consulted the medieval Latin versions wherever these were available, ${ }^{137}$ although his superior expertise in Greek philology and wider knowledge of Greek philosophy meant that he worked primarily on the original sources. Regarding the Elementatio theologica, there is some evidence that he may himself have made a new translation of this work: namely, glosses in the manuscript on which he based his translation of Plotinus - MS Paris, BnF, gr. 1816 - that are possibly fragments of his version of the Elementatio. ${ }^{138}$ However, Ficino seems to have soon lost interest in any such a project as may have existed, for the glosses referring to Proclus' treatise in the Plotinus

H.-G. Senger (ed.), Cusanus-Texte III. Marginalien. 2. Proclus Latinus. Die Exzerpte und Randnoten des Nikolaus von Kues zu den lateinischen Übersetzungen der Proclus-Schriften. 2.1. Theologia Platonis - Elementatio theologica (Heidelberg:Winter, 1986); and K. Bormann (ed.), Cusanus-Texte III. Marginalien. 2. Proclus Latinus. Die Exzerpte und Randnoten des Nikolaus von Kues zu den lateinischen Übersetzungen des Proclus-Schriften. 2.2. Expositio in Parmenidem Platonis (Heidelberg: Winter, 1986).

133 Nicholas of Cusa, De non-aliud, h XIII, c. 1, p. 3, l. 2-7.

134 Nicholas of Cusa, De venatione sapientiae, h XII, c. 8, §21, l. 7-9.

135 Nicholas of Cusa, De venatione sapientiae, h XII, c. 17, §49, l. 3-8; and c. 22, §64, l. 7-12.

${ }_{13} 6$ For a survey of Ficino's reading of Proclus see M.J.B. Allen, "Marsilio Ficino", in S. Gersh (ed.), Interpreting Proclus. From Antiquity to the Renaissance (Cambridge: Cambridge University Press, 2014), p. 353-379.

137 See C. Steel, "Ficino and Proclus. Arguments for the Platonic Doctrine of the Ideas", in J. Hankins, F. Meroi (eds), The Rebirth of Platonic Theology, p. 63-118, especially at p. 93-94.

${ }_{13} 8$ There is also an apparent reference to a translation in a letter dated 1474. On the testimony and "fragments" see D. Robichaud, "Fragments of Marsilio Ficino's Translations and Use of Proclus' Elements of Theology and Elements of Physics. Evidence and Study", in Vivarium 54(2016), p. 46-107, at p. 49-5o. 
manuscript are not repeated in the corresponding passages within the Plotinus commentary that was composed later on. ${ }^{139}$ Regarding the Theologia Platonis, there is evidence in his letter to Martin Prenninger of 17 June 1489 referring to a Latin translation of the work that Ficino knew Balbi's translation or at least knew of it. ${ }^{140}$ However, his notes on the Greek text in the Ms Firenze, Bibl. Riccard. 70 show clearly that he studied also the larger theological treatise primarily in the original language. ${ }^{141}$ In addition, Ficino undoubtedly used the original texts of Proclus' commentaries on the Timaeus and Parmenides in connection with his own commentaries on those dialogues, also producing his own translations of extracts from Proclus' commentaries on the Republic ${ }^{142}$ and First Alcibiades. ${ }^{143}$

\subsection{Proclus as Preeminent Platonist}

The high valuation placed on Proclus by medieval Platonists was based on the philosophical richness of his writings buttressed by his presumed dependence on the authority of Dionysius the Areopagite. This doctrinal dependence - the order of which is now known to be reversed - was assumed by our three central figures. Doubts about the genuine apostolic authenticity of the Dionysian corpus had existed since it first appeared on the scene and in both the eastern and western sectors of medieval Christendom. However, it was not until the rise of humanism in the fifteenth century and especially after the work of Lorenzo Valla and Desiderius Erasmus that decisive proof of the Dionysian pseudepigraphy was obtained.

Nicholas of Cusa's contribution to the fifteenth-century debate is strangely detached or ambivalent. An annotation in one of this writer's MSs of Dionysius states his amazement that neither Augustine nor Jerome cites Dionysius who is mentioned as an authority only many years later by John Damascene and

139 However, Ficino refers to the work in a letter of 1492: namely, Epistulae, lib. XI, 28, Opera omnia, p. 937.

140 Ficino, Epistulae, lib. IX, 12, Opera omnia, p. 899. The same letter also refers to the Latin version of the Tria opuscula.

141 See H.-D. Saffrey, "Notes platoniciennes de Marsile Ficin dans un manuscrit de Proclus (Cod. Riccardianus 70)", in Bibliothèque d'Humanisme et de Renaissance 21(1959), p. 161-184.

142 At Epistulae, lib. XI, 28, Opera omnia, p. 937, he speaks of having in 1492 obtained six books and the beginning of the seventh of this work and of having translated some extracts. However, Ficino never obtained access to a complete ms.

143 Ficino also translated a short work of Proclus about theurgy to which he gave the Latin title De sacrificio et magia. 
Gregory the Great. ${ }^{144}$ There is also a letter from Nicholas to Valla dated $145^{\circ}$ in which he requests permission from the latter to have copied his In Novum Testamentum Annotationes which Nicholas has already read in a borrowed copy. ${ }^{145}$ The Cardinal must therefore have been familiar with Valla's critique of the apostolic status of Dionysius. However, there is no evidence in Nicholas' published writings - even after 1450 - that he questioned the authority of a source which remained equally canonical for Berthold and Ficino.

6.4.1 Berthold of Moosburg

There is plenty of circumstantial evidence suggesting that Berthold of Moosburg adopts the standard medieval viewpoint regarding the priority of Dionysius to Proclus. In a position of strategic significance near the beginning of his Expositio tituli, he argues that the Lycian thinker's theological excellence resides in his ascending to knowledge of the supreme Good "through the triplicity of motions that Dionysius in chapter 4 of On Divine Names [section $\mathrm{K}$ ] ascribes both to angels and souls: that is, the circular, the rectilinear, and the oblique" ("per triplicem motum quos ascribit Dionysius 4 cap. De Divinis Nominibus $K$ et angelis et animabus: scilicet circularem, rectum et obliquum»). ${ }^{146}$ This statement seems to confirm that Berthold believes Proclus to have lived subsequently to Dionysius and to have been influenced by him. After this passage, when the German commentator goes on to connect the three Dionysian motions with different psychic faculties and their uses by drawing upon a discussion not in Proclus' Elementatio but in his De providentia et fato, we can assume that he sees this Proclus text and others like it as extended glosses on the Areopagite. ${ }^{147}$

\subsubsection{Nicholas of Cusa}

Nicholas of Cusa provides a fairly detailed analysis of what he takes to be the historical relation between Proclus and Dionysius in a chapter of De venatione

144 ms Bernkastel-Kues, Cod. Cus. 44, fol. 1v published by L. Baur (ed.), Cusanus-Texte III. 1. Marginalien. 1 Nicolaus Cusanus und Ps.-Dionysius im Lichte der Zitate und Randbemerkungen des Cusanus (Heidelberg:Winter, 1941), p. 19. On the Cusanus-Valla connection see E.N. Tigerstedt, The Decline and Fall of the Neoplatonic Interpretation of Plato. An Outline and Some Observations (Helsinki: Societas Scientiarum Fennica, 1974), p. 22-24.

145 The letter is only extant as included in Valla's Antidotum in Poggium III. It is discussed in detail by L. Barozzi, R. Sabbadini, Studi sul Panormita e sul Valla (Firenze: Le Monnier, 1891), p. $127 \mathrm{ff}$.

146 Berthold of Moosburg, Expositio, Expos. tit. A, p. 37, l. 3o-p. 38, l. 34.

147 Proclus, De providentia et fato, ed. D. Isaac (Paris: Les Belles Lettres, 1979), c. 4, §17-19, p. 41, l. $1-$ p. 44 l. 32. 
sapientiae. ${ }^{148}$ In the course of discussing how philosophers have surveyed the conjectural "field of Unity" (campus unitatis), Nicholas notes the practice of denying all attributes of the One as a means of establishing its transcendence. He then explains that the book Parmenides shows how Plato made the pursuit of the One by means of logic, that Proclus "sums up" (epilogat) this teaching in the second book of his Platonic Theology, and that Dionysius "imitates" (imitatur) Plato in a similar pursuit of the One. ${ }^{149}$ Although Nicholas' argument establishes that both Proclus and Dionysius follow Plato, he has not been explicit concerning the relative priorities of the two later writers. This omission is rectified in a passage in De non-aliud where the Cardinal notes that Proclus "came after Dionysius" (post Dionysium venit) because he cites Origen ${ }^{150}$ who himself came after Dionysius, ${ }^{151}$ and that Proclus "follows Dionysius" (Dionysium sequendo) in denying both unity and goodness of the First whereas Plato called the First both one and good. ${ }^{152}$

\subsubsection{Marsilio Ficino}

There are explicit statements by Marsilio Ficino indicating that he also endorses the prevailing view concerning the priority of Dionysius to Proclus. One example can be found in a passage where Ficino is commenting on the Plotinian notion that evil consists of a falling short of the law contained in the divine mind and in nature, and then connects this with the doctrine that evil is not existent but only quasi-existent in Proclus who "in my opinion, follows in the wake of Dionysius the Areopagite" ("Dionysium, ut arbitror, secutus Areopagitam"). ${ }^{153}$ That Ficino was conscious of the problem concerning the absence of references in the early Church Fathers to the Dionysian Corpus is indicated in a letter noting his "frequent suspicion" (saepe [...] suspicari) that the Platonists who preceded Plotinus such as Ammonius, Numenius and maybe some of their predecessors had read the works of Dionysius "before they were hidden away" (antequam [...] delitescerent) as a result of some unknown calamity to the Church. ${ }^{154}$

148 The argument of the following paragraph expands some earlier comments at Nicholas of Cusa, De beryllo, h XI/1, §12, l. 11-12.

149 Nicholas of Cusa, De venatione sapientiae, c. 22, §64, p. 62, l. 3-20.

150 The reference is to Proclus, Theologia platonica, lib. II, c. 4, p. 31, l. 1-9.

$15^{1}$ We have supplied what seems to be Nicholas' missing premiss.

$15^{2}$ At De non-aliud, h XIII, c. 20, p. 47, 1. 23-26, Nicholas says that it is unclear whether Proclus had actually read Dionysius.

153 Marsilio Ficino, In Enneadem III. 2, §23. The references are to Proclus, De malorum subsistentia, c. 2, §11-39 and c. 3, §49, and Dionysius, De divinis nominibus, c. 4, §18-35, 713D-736B.

154 Marsilio Ficino, Epistulae, lib. XI, 3, Opera omnia, p. 925. 


\subsection{Changing Attitudes to Proclus' Doctrine}

In turning from the consideration of the later Platonists' view of Proclus' historical position in relation to philosophy and Christianity to their view of his actual doctrine, we will attempt to pursue the analysis in two directions. On the one hand, a conceptual trajectory in the case of our selected authors will be traced consisting of their increasing awareness of - or willingness to acknowledge - the inherent paganism of Proclus' doctrine indicated by its emphatic polytheism. On the other hand, we will discern a double or inverted trajectory in the same authors' thinking comprising a decline of their apparent interest in Proclus' axiomatic theory and - in a complementary relation to that - a noticeably heightened interest in his doxographical content.

6.5.1 Increasing Recognition of Proclus' Inconsistency with Christianity 6.5.1.1 Berthold of Moosburg

Berthold's Expositio obviously has to take account of a prominent feature of Proclus' original text - reinforced by the Tria Opuscula and the Commentarius in Parmenidem [only its first part] -: namely, its contention that reality includes a hierarchical chain of causality subsequent to the First Cause - the One or Good - that begins from a series of "gods" (dei) or "unities" (henades / monades). Given that Dionysius explicitly rejects the notion that there are "many causes and divinities causing one another in a hierarchy of higher and lower" ("polla ta aitia kai allōn allas paraktikas theotētas huperechousas kai hupheimenas") ${ }^{155}$ - which is precisely the doctrine advocated by Proclus in the Elementatio -, it was obviously necessary for Berthold to start from the earlier scholastic practice when dealing with Proclus of assimilating the latter's gods or unities somehow to transcendent Forms, and then to insert these principles into the framework provided by the Dionysian doctrine of the single God's names. Presenting in summary form ${ }^{156}$ the information contained in three passages in the early part of his Expositio, ${ }^{157}$ we can say that Berthold establishes the following hierarchical plan of the divine world consisting of four distinct levels: Level 1 - The First One and Good $<\mathrm{A}>; 158$ Level 2 - the gods of

155 Dionysius, De divinis nominibus, 5.2, 816C.

${ }_{15}$ In order to simplify things, we here omit much of the intertextual component which includes references to Boethius, De consolatione philosophiae, lib. III. pr. 10, §85-6; Macrobius, In Somnium Scipionis, lib. I, c. 6, §5-6, and an abundance of biblical citations.

157 Berthold of Moosburg, Expositio, Prol. 4, p. 12, l. 227-p. 13, l. 25 o [= passage A]; Prol. 5, p. 13, l. 254-263 [= passage B]; Prol. 11, p. 19, l. 451-471 [= passage C]; Prol. 12, p. 21, l. 524-535 [= passage $D]$.

$15^{8}$ For the reader's greater convenience, the different passages in Berthold's text are indicated with letters $A-D$. See the previous note. 
Proclus' Elementatio - equivalent to unities or goodnesses in themselves, "selfsufficient" (autoteleis $=$ per se perfecta) terms $<\mathrm{A}>$, that are seven in number $<\mathrm{C}>$, equivalent to the "primordial causes" (primordiales causae) of Augustine, Eriugena, and the Clavis physicae $<\mathrm{B}>$, "unparticipated" (amethecta) terms $\langle\mathrm{D}\rangle$, and comprising goodness, infinity, ${ }^{159}$ being, life $\langle\mathrm{BC}\rangle$, intellectuality, animality, and naturality $\langle\mathrm{C}>$; Level 3 - Numerous unities in participants $\langle\mathrm{A}\rangle$, terms having substances in themselves, being [a primary group of ] ${ }^{160}$ effects of the primordial causes $\left\langle\mathrm{B}>\right.$, participated terms $\langle\mathrm{A}\rangle$, and comprising infinities, ${ }^{161}$ beings, lives $\langle\mathrm{B}>$, intellectualities, animalities, and naturalities $\langle\mathrm{BD}>$; Level $4-$ Divine and intellectual souls $\langle\mathrm{BD}\rangle$, terms having substances in other things, being [a secondary group of] effects of primordial causes $\langle\mathrm{B}>$, and participating terms $\langle\mathrm{B}\rangle$. As a result of the idealistic turn of his thought prompted by his studies of Augustine, Eriugena and the Clavis physicae, ${ }^{162}$ Berthold manages to effect a rather successful reconciliation between Proclus and Dionysius by aligning the former's elaborate stratification of real principles with (partially mind-dependent) modalities of the single participatory relation associated with each of the Dionysian divine names.

In his Theologia platonica, Proclus had arranged his gods less as the highest of a number of superimposed series of metaphysical principles than as the unitary initial moments of triadic structures discerned between and within the primary hypostases of being, life, and intellect. The second book of Proclus' work also includes an explanation of how this theological doctrine had been elaborated in the second part of his commentary on the Parmenides: a useful feature for medieval readers in that the relevant material was missing from the manuscript used by Moerbeke for his Latin version and has still not been recovered. In addition, the gods of Proclus' Theologia platonica were less the abstract causes of hierarchies of metaphysical principles than the concrete allegorical personifications of such causes in the imagery of Orphic and "Chaldaean" religious cult. In turning from Berthold to Nicholas and Ficino, we find the two later thinkers grappling in ways that are both similar and divergent with the

159 "Infinity" and the other terms are here naturally singular.

160 We here distinguish a primary and secondary group by name, since both the structuring of his system and Proclus' original doctrine clearly requires it. In fact, Berthold's own explanation was not written with the utmost clarity at this point, for he on occasion conflates levels $3+4<\mathrm{AB}>$, whereas at other times he separates them $<\mathrm{CD}>$.

161 "Infinities" and the other terms are here naturally plural.

162 On the important aspect of Berthold's use of Eriugena and the Clavis physicae for the formation of his general viewpoint see E. Ludueña, La recepción de Eriúgena en Bertoldo de Moosburg. Un aporte sobre la Escuela de Colonia (Saarbrücken: Publicia, 2013) and E. King, Supersapientia. A Study of the Expositio super Elementationem Theologicam Procli of Berthold von Moosburg, PhD diss. (University of Cambridge, 2016). 
more intractable polytheism of Proclus' most substantial and definitive treatment of Greek theology.

\subsubsection{Nicholas of Cusa}

We will never know exactly what Nicholas of Cusa thought of Berthold of Moosburg's ingenious explanation of Proclus' gods - other than the fact that he included the commentary of "John of Mossbach" in his list of forbidden books. ${ }^{163}$ However, the Cardinal reports in considerable detail his critical encounter with this more overtly cultic version of polytheism in Proclus' Theologia platonica in numerous passages of his De beryllo, ${ }^{164}$ De principio, ${ }^{165}$ De non-aliud, ${ }^{166}$ and De venatione sapientiae ${ }^{167}$ in most of which he sets out from a discussion of the metaphysical doctrine of the One and the One-Being in Plato's Parmenides as explained by Proclus. The sermon-treatise De principio ${ }^{168}$ displays with particular clarity Nicholas' twofold strategy of maintaining the theological reading of the dialogue while driving a wedge between the acceptable negative and affirmative theology of Proclus and his unacceptable polytheism. ${ }^{169}$

Nicholas begins here by stating the positive aspects of Proclus' doctrine. This is correct in distinguishing as two modes of being: the One that is the absolute and un-participated cause of the multiplicity of things and the One-Being that is the contracted and participated cause of the multiplicity and the being of things. ${ }^{10}$ The phraseology here aligns the Platonist's distinction with his own standard dichotomy of absolute and contracted Maximum. ${ }^{171}$ However, Nicholas immediately follows this statement with a negative remark. Proclus is incorrect in arguing that the One-Being is participated in a primary way by "other gods" (alii dei), ${ }^{172}$ and is a "multiplicity co-eternal" (plura [...]

163 There is a deep affinity between Berthold and Nicholas in that both thinkers similarly developed an idealistic standpoint on the basis of reading Eriugena and the Clavis physicae. See above.

164 Nicholas of Cusa, De beryllo, h XI/1, §12, l. 11-§13, l. 12.

165 Nicholas of Cusa, De principio, h x/2b, p. 8, l. 11-18 and p. 39, l. 1-33.

166 Nicholas of Cusa, De non-aliud, h XIII, c. 20-22, p. 47, l. 29-p. 53, l. 30

167 Nicholas of Cusa, De venatione sapientiae, h XII, c. 21-22, §59, l. 1-\$64, l. 20.

168 Here, Nicholas treats Plato and Proclus in tandem, his assumption being that the latter's commentary approximates to the original teaching of the former.

169 We know from other statements in Nicholas' writings that he approves the theological reading of the Parmenides as long as that is maintained on Dionysius' terms.

170 Nicholas of Cusa, De principio, h x/2b, p. 39, l. 1-34.

171 As stated in De docta ignorantia and elsewhere.

172 Nicholas of Cusa, De principio, h x/2b, p. 40, l. 1-12. 
coaeterna) with the One. ${ }^{173}$ The critique is now amplified in two stages. In the first stage, he states the theological doctrine elaborated by Proclus after the first two hypotheses of the Parmenides and summarised in his Theologia Platonis as follows: $a$. there is a distinction between the One and the One-Being; $b$. there is a division of the One-Being - or the participated being or the contracted being - into three modes of being called being, life, and intellect; a further division of life - the second mode of being - into a simple unity, the unitary life, and the multitude of lives; and a further division of intellect - the third mode of being - into a simple unity, the unitary intellect, and the multitude of intellects; ${ }^{174} c$. the One is identified with the First God who exercises a universal providence; $d$. the multiple divisions of the One-Being are identified with secondary gods who exercise partial providence, these secondary gods - who participate in the First God in a primal manner - including a division into intellectual gods, celestial gods, and cosmic gods; $e$. the First God is identified with Jupiter and one of the secondary gods who preside over mechanical arts with Vulcan. ${ }^{175}$ In the second stage, Nicholas attacks the obvious polytheism of this doctrine by turning the arguments of Parmenides and Zeno in the first part of the Parmenides against the doctrine of a multiplicity of self-subsistent principles such as Forms co-eternal with the One extracted by Proclus from the second part of the dialogue. ${ }^{176}$

\subsubsection{Marsilio Ficino}

Ficino's main contribution to this debate can be found in two texts: a short argumentum ("analytical study") forming the preface to his translation of the Parmenides in his Platonis Opera omnia volume of $1484^{177}$ and a lengthy

173 Nicholas of Cusa, De principio, h x/2b, p. 25, l. 1-18. At De venatione sapientiae, h XII, c. $21, \S 62,1.1-12$, he notes that Proclus is incorrect in treating the One-Being as a divine species participating in the One.

174 Nicholas of Cusa, De principio, h x/2b, p. 39, l. 1-34.

175 Nicholas of Cusa, De principio, h x/2b, p. 40, 1. 1-14. There is perhaps a briefer reference to the doctrine of Proclus' Theologia Platonis concerning God and the opposition of motion and rest at De possest, $\mathrm{h} \mathrm{XI} / 2, \mathrm{p} .21, \mathrm{l}$. 1-13.

176 Nicholas of Cusa, De principio, h x/2b, p. 25, l. 1-p. 3o, l. 22.

177 Marsilio Ficino, Argumentum in Parmenidem, Opera omnia, p. 1136-1137. The short argumentum explains that the aim of the dialogue is to study how the One is above all things and how all things are derived from it. In order to accomplish this, it ascends through levels of unity starting from the sensible sphere, passing through that of intelligibles and Ideas, and culminating in the reason-principle of the Ideas. Ficino lists the quaestiones concerning the Ideas in the first part of the dialogue and notes the arrangement of the hypotheses in the second part. By adopting all these typically Proclean positions, it is clear that Ficino was familiar with the later Neoplatonic exegesis of the dialogue by 1484 at the latest. 
commentary published in the collected edition of his Plato commentaries in 1496. It is in the latter that his critical encounter with the more overtly cultic version of polytheism in Proclus' Theologia platonica is worked out in detail. As in the case of Nicholas of Cusa, there is a twofold strategy of maintaining the theological reading of the dialogue while driving a wedge between the acceptable negative and affirmative theology of Proclus and his unacceptable polytheism. In so doing, he at the same time adopts a relatively polite yet firm critical stance against an interpretation of the same dialogue recently publicised by his former student and "fellow Platonist" Giovanni Pico della Mirandola.

We need to consider three extracts from the Parmenides Commentary. In the first passage, Ficino summarises the view of Syrianus and Proclus regarding the threefold ordering of the super-mundane gods into the intelligible, the intelligible-and-intellectual, and the intellectual gods; and of the mundane gods into the souls of the greater spheres, the souls of the stars, and the invisible divinities within the spheres. This is described as part of the Platonists' attempt to demonstrate that Parmenides "introduces precisely as many orders of gods as he posits propositions in the first and second hypotheses" ("totidem ad unguem deorum ordines introducere quot propositiones in prima secundaque suppositione ponit"). ${ }^{178} \mathrm{~A}$ second passage adopts a critical stance with respect to this obvious polytheism by warning against the method of "calculating the number of individual gods in accordance with that of individual phrases" ("cum clausulis singulis deos singulos computare"). ${ }^{179}$ In the third passage, Ficino concludes that Parmenides conducts the entire disputation in the second half of the dialogue not as the dogmatic unfolding of a complete metaphysical system but as a logical exercise designed to test the hearers' intelligence. He argues that "underneath this dialectical form Parmenides also frequently blends in mystical teachings" ("sub hac vero dialectica forma mystica quoque dogmata frequenter admiscet") not everywhere and continuously in his discourse but scattered at whatever points the logical exercise might permit. ${ }^{180}$ Thus, Ficino pursues the same strategy as did Nicholas in undermining the polytheism of Proclus' text, although he does so in this case not by setting the first part of the Parmenides against the second but by distinguishing the latter's surface and deeper meanings.

178 Marsilio Ficino, Commentum in Parmenidem, part II, c. 94, §2-3, p. 238-240.

179 Marsilio Ficino, Commentum in Parmenidem, part II, c. 94, §3-4, p. 240-242.

180 Marsilio Ficino, Commentum in Parmenidem, part II, c. 9o, §2, p. 220-222. 
6.5.2 Declining Interest in Proclus' Axiomatics and Increasing Interest in his Doxography

6.5.2.1 Berthold of Moosburg

Berthold of Moosburg had understood, and rightly so, that the most important feature of the Elementatio was its axiomatics. ${ }^{181}$ At the beginning of his Expositio tituli, he explains that Proclus was one of the most eminent of Plato's disciples - something reflected in the etymology of his name: "famed far and wide" (procul cluens) ${ }^{182}$ - and then makes two fundamental exegetical moves. ${ }^{183}$ Berthold's first exegetical move is to combine two doxographical passages in Augustine's Contra Academicos: ${ }^{184}$ a passage referring to the Platonists' deliberate concealment of their doctrine examined earlier; ${ }^{185}$ and a passage identifying Plotinus as the thinker who dispersed the clouds of error surrounding Plato's work. ${ }^{186}$ With respect to the latter passage, Berthold alters the gist of the Augustinian original on the one hand, by associating Proclus very closely with Plotinus in relation to the definitive disclosure of Platonic truth, since he notes that "the countenance of Plato blazed forth especially in him" - i.e. Proclus - "just as it had done also in Plotinus" ("emicare maxime in eo sicut et in Plotino os illud Platonis"). On the other hand, he shifts the sense of Augustine's statement by interpreting the definitive disclosure as the discovery of literal truth concealed behind allegory, for he glosses the "clouds of error" [nubes = non-technical term] as "the coverings with which the first Platonists and especially the Academics had enwrapped their wisdom" ("integumenta [...] quibus Platonici primi et maxime Academici suam sapientiam obvolvebant") [integumenta = technical term for allegory]. Berthold's second exegetical move is to interpret the doctrine of Plato, now identified with that of Proclus, as an axiomatic system. ${ }^{187} \mathrm{He}$ writes that Proclus "arranged the theorems of Plato himself in the present book and most subtly elucidated them once arranged" ("ipsius Platonis theoremata ordinavit in praesenti libro et ordinata subtilissime declaravit"). The evidence for this is provided by an

181 On Berthold's axiomatics see S. Gersh, "Berthold von Moosburg on the Content and Method of Platonic Philosophy", in J. Aertsen, K. Emery, A. Speer (eds), Nach der Verurteilung von 1277. Philosophie und Theologie an der Universität von Paris im letzten Viertel des 13. Jahrhunderts. Studien und Texte (Berlin / New York: De Gruyter, 2001), p. 493-503.

182 Berthold of Moosburg, Expositio, Expos. tit. A, p. 37, l.10-13. The etymology is derived from Papias.

183 Berthold of Moosburg, Expositio, Expos. tit. A, p. 37, l. 14-29.

184 Berthold of Moosburg, Expositio, Expos. tit. A, p. 37, l. 14-24.

185 Augustine, Contra Academicos, lib. III, c. 20, §43.

186 Augustine, Contra Academicos, lib. III, c. 18, §41.

187 Berthold of Moosburg, Expositio, Expos. tit. A, p. 37, l. 25-29. 
intertextual citation of Eustratius' Commentary on the Nicomachean Ethics. Berthold notes that "Plato handed down theorems regarding the primal Good that should be thought not as insignificant but as important and leading souls towards the greatest heights" ("Plato de primo bono tradidit non contemptibilia theoremata, sed magna et in excelsum maximum animas referentia"). ${ }^{188}$

The axiomatic aspect of Proclus' theology has in reality a certain ambivalent status, on the one hand having discursive thinking as its defining characteristic, but on the other being a vector towards its own transcendence in the non-discursive or mystical sphere. That Berthold understood this well enough is shown by his intertextual explanation of the propositional method in the Elementatio in terms of the ladder linking the theta and $p i$ on Philosophia's robe in Boethius' Consolatio. ${ }^{189}$ However, the ambiguity of Proclus' methodology was perhaps too much for the next generations of medieval Platonists who, if they were familiar with Berthold's Expositio at all, decided to assimilate the Greek philosopher in a different way. In fact, the subsequent course of the latter's influence can be charted by studying the double or inverse conceptual trajectory mentioned earlier: namely, a reduction of interest in Proclus' axiomatic system - taken at its face-value - complemented by an increase of interest in his doxographical content.

\subsubsection{Nicholas of Cusa}

Many of the extant philosophical and theological books in Nicholas of Cusa's library have abundant glosses in the master's hand. This is particularly true with respect to his copies of the Moerbeke translations of Proclus although, while the annotations on the Theologia platonica are fairly extensive, those on the Elementatio theologica are brief and perfunctory. ${ }^{190}$ Of course, it may be that the Cardinal's earlier study of the latter was illustrated in manuscripts of his that are no longer extant. However, it is more likely that these insignificant notes reveal how much his thought had moved away from a form of Platonism that compromised so readily with the axiomatic taste of the schoolmen. ${ }^{191}$ In

188 Eustratius, In Ethicam nicomacheam Commentarius, ed. G. Heylbut (Berlin: Reimer, 1892), lib. I, c. 4, p. 39, l. 32-34. Of course, Berthold read this work in the Latin translation: In Ethicam nicomacheam Commentarius, translatio Roberti Grosseteste, ed. H.P.F. Mercken, The Greek Commentaries on the Nicomachean Ethics of Aristotle in the Latin Translation of Robert Grosseteste, Bishop of Lincoln. Volume 1. Eustratius on Book I and the Anonymous Scholia on Books II, III, and IV (Leiden: Brill, 1973).

189 See above.

190 See Senger, Cusanus-Texte III.

191 This propensity is indicated by the enormous influence among the Schoolmen of another very axiomatic work: the Arabic-Latin De causis. It is perhaps no accident that Nicholas of Cusa also makes very little use of this text. 
Nicholas' case, the axiomatic approach can be seen as replaced by his doctrine of "conjectures". He explains this notion in the first book of De coniecturis 192 where he contrasts on the one hand, "unity of truth" (veritatis unitas) and on the other hand, "conjectural otherness" (alteritas coniecturalis). He notes that, since precision of truth is unattainable by human beings because of the lack of proportion between truth and the intellect, any "positive assertion" (positiva assertio) about truth must be conjectural. ${ }^{193}$ In Nicholas' case also, the axiomatic approach can be seen as replaced by his doctrine of "coincidence of opposites". Having devoted a major work to this notion in the specific form of "learned ignorance" (docta ignorantia), he found himself having to defend it against the attacks of the neo-scholastic Johannes Wenck. He replies by arguing that the law of contradiction is something established by prolonged acceptance among the currently dominant Aristotelian faction rather than a universal law. ${ }^{194}$ But then, a student of Proclus' axiomatics would realise that acceptance of the law of contradiction was indispensable for such a project.

\subsubsection{Marsilio Ficino}

For Berthold, the axiomatics is equivalent to the mystery concealed in the Platonic tradition and revealed by Proclus in the Elementatio theologica, whereas for Ficino, the axiomatics would be equivalent to what conceals the mystery. ${ }^{195}$ But the Florentine's position on this question is somewhat hypothetical, since he never addresses this question directly, being interested less in Proclus the logician than in Proclus the doxographer. ${ }^{196}$ This change of focus with respect to the earlier tradition runs parallel with a shift in interest from Proclus' Elementatio theologica to his Plato commentaries and especially to those on the Timaeus and Republic now available in Greek. ${ }^{197}$ Two

192 J. Koch, Die Ars coniecturalis des Nikolaus von Kues (Köln: Westdeutscher Verlag, 1956), discusses the nature of this doctrine and suggests various possible historical sources.

193 Nicholas of Cusa, De coniecturis, h III, prol., p. 2, l. 1-12. Cf. De docta ignorantia, h I, lib. I, c. 1, p. 5, l. 1-p. 6, l. 24.

194 Nicholas of Cusa, Apologia doctae ignorantiae, h II, p. 6, l. 3-12. We cannot go into detail here concerning the many ways in which Nicholas "recommends" - obviously he cannot "prove" - the coincidence of opposites.

195 As does similarly the demonstration by the chief protagonist in Plato's Parmenides. See above.

196 On the possible traces of a commentary on the Elementatio theologica by Ficino, see above.

197 On this material see P. Megna, "Marsilio Ficino e il Commento al Timeo di Proclo", in Studi medievali e umanistici 1(2003), p. 93-135; and P. Megna, "Per Ficino e Proclo", in F. Bausi, V. Fera (eds), Laurentia Laurus. Per Mario Martelli (Messina: Centro interdipartimentale di studi umanistici, 2004), p. 313-362. 
examples of Ficino's doxographical use of Proclus may perhaps suffice here. In the Compendium in Timaeum, Ficino considers the possible doubts of a reader as to whether Plato really thought the world to be everlasting, and then replies explicitly on the authority of Proclus ${ }^{198}$ that some commentators such as Severus, Atticus, and Plutarch did not consider the world to be everlasting, whereas others such as Crantor, Plotinus, Porphyry, Iamblichus, and Proclus understood it to be perpetually flowing forth from God. ${ }^{199}$ In the Argumentum in Critiam, Ficino discusses the causes of human intelligence and reports once again according to Proclus ${ }^{200}$ that, whereas Panaetius believes this to be the moderate warmth of the air, Longinus rather the blended quality of the region, and Origen rather the celestial aspects and emanations, Porphyry and Proclus himself seek the causality higher up in the world-soul and in the demiurgic intellect. ${ }^{201}$ Passages such as these in which Ficino explicitly cites the source of his doxography can be supplemented by many others clearly identifiable as borrowed from Proclus through the presence of absolutely identical clusters of the more ancient authorities in both writers' texts.

Marsilio Ficino's translations of the complete works of Plato and Plotinus, to which he added a range of shorter and longer commentaries, obviously marks a decisive turning-point in the history of philosophy. During the western medieval period when Plato's works were largely unavailable, Proclus had gradually risen to prominence as the definitive source of ancient Platonism. But from 1484 onwards when the Latin translation of Plato's writings appeared, it is Plotinus who largely replaces Proclus, thereby recapturing the preeminent position within the Platonic tradition assigned to him by Augustine. ${ }^{202}$

Various of his letters and prefaces indicate that Ficino began the work of translating Plotinus in 1463 on the basis of the ms supplied by Cosimo de' Medici (Firenze, Bibl. Med. Laur., Plut. 87. 3) and another one (Paris, BnF,

\footnotetext{
198 "as Proclus recounts" (ut Proclus narrat).

199 Marsilio Ficino, Compendium in Timaeum, Opera omnia, c. 13, p. 1443. The reference is to Proclus, In Timaeum Commentaria, ed. E. Diehl, 3 vols (Leipzig: Teubner, 19०3-19o6), vol. 1, lib. I, p. 277, 1. 8-16.

200 "Proclus says that ..." (Proclus ait ...).

201 Marsilio Ficino, Argumentum in Critiam, Opera omnia, p. 1486-1487. The reference is to Proclus, In Timaeum, lib. I, p. 162, l. 11-3o.

202 For an introduction to the Plotinus commentary see S. Gersh, "Analytical Study", in S. Gersh (ed.), Marsilio Ficino: Commentary on Plotinus, Ennead I.
} 
gr. 1816) copied from it, both these extant Mss containing annotations in his hand. ${ }^{203}$ The commentaries prefixed to the translation reached their final form by 149o. It was in the spring of that year that the entire work was presented in a luxurious manuscript to its dedicatee, Lorenzo de' Medici, this manuscript being now catalogued as MS Bibl. Med. Laur., Plut. 82. 10. and 82. 11. The printed edition appeared from the press of Antonio Miscomini in May 1492. This chronology shows that Ficino spent roughly thirty years working on Plotinus, while the content of his other writings shows that he had thoroughly mastered Plotinian thought by the early 1470 os. $^{204}$ Among the latter are the commentary on the Symposium (= De amore), the first redaction of the commentary on the Philebus, and especially the Platonic Theology (eighteen books). Given the assumption that Plotinus was the philosopher who had resolved the enigmas in Plato's dialogues, ${ }^{205}$ it is fair to conclude that for Ficino the philosophies of Plato and Plotinus were only distinct from one another on the rhetorical surface.

It is possible to reconstruct the process of composing the Commentary on the Enneads in some detail. ${ }^{206}$ We know that Ficino worked in the order of the Porphyrian edition and had completed the commentary up to the first two treatises of the Third Ennead by 1487 after which a two-year gap intervened in which he worked instead on translations of various works by other Neoplatonists such as Porphyry, Iamblichus, Proclus, and Synesius. He then returned to Plotinus but soon after decided to write only shorter commentaries in order to prevent the whole project from becoming out of hand. ${ }^{207}$

Ficino's work on these other Neoplatonists made a significant contribution to the development of his own personal philosophy and to the dissemination of late ancient philosophy in general. In addition to his introduction of certain writings by Proclus that had not been known in western Europe during the Middle Ages, ${ }^{208}$ his translations of Porphyry's De abstinentia and De occasionibus (= the Aphormai pros ta noèta), of Iamblichus' De mysteriis, and of Synesius' De insomniis helped to propagate a radically new interpretation of

203 On these mss see C. Förstel, "Marsilio Ficino e il Parigino Greco di Plotino", in S. Gentile, S. Toussaint (eds), Marsilio Ficino, fonti, testi, fortuna. Atti del convegno internazionale, Firenze 1-3 ottobre 1999 (Roma: Edizioni di Storia e Letteratura, 2006), p. 65-88.

204 This judgment is based on the dates of composition - which are mostly known - rather than those of publication.

205 See above.

206 The narrative was constructed on the basis of references in Ficino's letters by P.O. Kristeller, Supplementum Ficinianum, 2 vols (Firenze: Olschki, 1937), vol. 1, p. cxxvi-cxxviii.

207 See Marsilio Ficino, In Enneadem IV.3, §33.

208 See above. 
Platonism in western Europe. Combining as he did the talents of philosopher, philologist, physician, and priest, Ficino not only further extended the general understanding of Neoplatonic theology and metaphysics but also brought into focus Plotinus' doctrines of contemplative nature and cosmic sympathy. In particular, he drew upon the theurgic tradition so prominently displayed in the post-Plotinian writings that he translated in order to develop a theory of natural magic which, especially in combination with the cabalistic magic of Giovanni Pico, established a tradition of "occult philosophy" extending from Cornelius Agrippa in the early sixteenth century down to the German Romantics.

\section{Bibliography}

\section{Manuscripts}

Bernkastel-Kues, Bibliothek des St. Nikolaus-Hospitals, Cod. Cus. 44.

\section{Primary Sources}

Albert the Great, Metaphysica, ed. B. Geyer, Münster i.W., Aschendorff, 196o. Augustine, De civitate Dei, eds B. Dombart, A. Kalb, Turnhout, Brepols, 1955.

Augustine, Contra Academicos. De beata vita. De ordine. De magistro. De libero arbitrio, eds W. Green, K. Daur, Turnhout, Brepols, 1970.

Berthold of Moosburg, Expositio super Elementationem theologicam Procli. Prologus, Propositiones 1-13, eds M.R. Pagnoni-Sturlese, L. Sturlese, Hamburg, Meiner, 1984.

Berthold of Moosburg, Expositio super Elementationem theologicam Procli. Propositiones 14-34, eds L. Sturlese, M.R. Pagnoni-Sturlese, B. Mojsisch, Hamburg, Meiner, 1986.

Boethius, De institutione arithmetica, ed. G. Friedlein, Leipzig, Teubner, 1867 (photographic reprint: Frankfurt a. M., Minerva, 1966).

Boethius, De consolatione philosophiae. Opuscula theologica, ed. C. Moreschini, München / Leipzig, Saur, 2005.

Calcidius, Commentarius in Timaeum, ed. J.H. Waszink, Timaeus a Calcidio translatus commentarioque instructus, London / Leiden, Warburg Institute / Brill, 1962.

Cicero, Academica, ed. O. Plasberg, Leipzig, Teubner, 1922.

Dionysius the ps.-Areopagite, De divinis nominibus, ed. B.R. Suchla, Berlin / New York, De Gruyter, 1990.

Dionysius the ps.-Areopagite, De coelesti hierarchia, De ecclesiastica hierarchia, De mystica theologia, Epistulae, eds G. Heil, A.M. Ritter, Berlin / New York, De Gruyter, 1991. Eustratius, In Ethicam nicomacheam Commentarius, ed. G. Heylbut, Berlin, Reimer, 1892. 
Eustratius, In Ethicam nicomacheam Commentarius, translatio Roberti Grosseteste, ed. H.P.F. Mercken, The Greek Commentaries on the Nicomachean Ethics of Aristotle in the Latin Translation of Robert Grosseteste, Bishop of Lincoln. Volume 1. Eustratius on Book I and the Anonymous Scholia on Books II, III, and IV, Leiden, Brill, 1973.

Hermes Latinus, Asclepius, eds A.D. Nock, A.-J. Festugière, Corpus Hermeticum, vol. 2, Paris, Les Belles Lettres, 1973.

Hermes Latinus, Le Livre des XXIV philosophes, ed. F. Hudry, Grenoble, Millon, 1989.

Hermes Latinus, Il Libro dei ventiquattro filosofi, ed. P. Lucentini, Milano, Adelphi, 1999. Hermes Latinus, Liber de VI rerum principiis, eds P. Lucentini, M.D. Delp, Turnhout, Brepols, 2006.

Lactantius, De ira Dei, eds S. Brandt, G. Laubmann, Opera omnia, part II, fasc. 1, Praha / Wien / Leipzig, Tempsky / Freytag, 1893, p. 65-132.

Lactantius, Divinarum institutionum libri septem, eds E. Heck, A. Wlosok, Berlin / New York, De Gruyter, 2005-2011.

Macrobius, Commentarius in Somnium Scipionis, ed. J. Willis, Leipzig, Teubner, 1970.

Marsilio Ficino, Marsilii Ficini [...] opera et quae hactenus extitere et quae in lucem nunc primum prodiere omnia [...], Basel, Heinrich Petri, 1576 (photographic reprint: Torino, Bottega d'Erasmo, 1959).

Marsilio Ficino, Three Books on Life, eds C.V. Kaske, J.R. Clark, Tempe, Arizona, Arizona Center for Medieval and Renaissance Studies, 2002.

Marsilio Ficino, Platonic Theology. Volume 6. Books XVII-XVIII, eds M.J.B. Allen, J. Hankins, Cambridge, Massachusetts, Harvard University Press, 2006.

Marsilio Ficino, Commentaries on Plato. Volume 2. Parmenides, Part 1 , ed. M. Vanhaelen, Cambridge, Massachusetts, Harvard University Press, 2012.

Marsilio Ficino, Commentaries on Plato. Volume 2. Parmenides, Part 2, ed. M. Vanhaelen, Cambridge, Massachusetts, Harvard University Press, 2012.

Marsilio Ficino, Commentary on Plotinus. Volume 4. Ennead III, Part 1, ed. S. Gersh, Cambridge, Massachusetts, Harvard University Press, 2017.

Marsilio Ficino, Commentary on Plotinus. Volume 5. Ennead III, Part 2, and Ennead IV, ed. S. Gersh, Cambridge, Massachusetts, Harvard University Press, 2018.

Marsilio Ficino, In Enneadem I, ed. S. Gersh, Cambridge, Massachusetts, Harvard University Press, forthcoming - the imprint possibly to be changed to Leiden: Brill in 2021.

Martianus Capella, De nuptiis Philologiae et Mercurii, ed. J. Willis, Leipzig, Teubner, 1983.

Nicholas of Cusa, Opera omnia, iussu et auctoritate Academiae Heidelbergensis ad codicum fidem edita, Hamburg, Meiner, 1932-20o6.

Nicholas of Cusa, Cusanus-Texte III. 1. Marginalien. 1 Nicolaus Cusanus und Ps.Dionysius im Lichte der Zitate und Randbemerkungen des Cusanus, ed. L. Baur, Heidelberg, Winter, 1941. 
Nicholas of Cusa, Cusanus-Texte III. Marginalien. 2. Proclus Latinus. Die Exzerpte und Randnoten des Nikolaus von Kues zu den lateinischen Übersetzungen der Proclus-Schriften. 2.1. Theologia Platonis - Elementatio theologica, ed. H.-G. Senger, Heidelberg, Winter, 1986.

Nicholas of Cusa, Cusanus-Texte III. Marginalien. 2. Proclus Latinus. Die Exzerpte und Randnoten des Nikolaus von Kues zu den lateinischen Übersetzungen des Proclus-Schriften. 2.2. Expositio in Parmenidem Platonis, ed. K. Bormann, Heidelberg, Winter, 1986.

Nicholas of Cusa, Cusanus-Texte III. Marginalien. 5. Apuleius. Hermes Trismegistus. Aus Codex Bruxellensis 10054-56, ed. P. Arfé, Heidelberg, Winter, 2004.

Plato, Meno interprete Henrico Aristippo, eds V. Kordeuter, C. Labowsky, London, Warburg Institute, 1940.

Plato, Phaedo interprete Henrico Aristippo, ed. L. Minio-Paluello, London, Warburg Institute, $195^{\circ}$.

Plato, Il Critone latino di Leonardo Bruni e di Rinuccio Aretino, eds E. Berti, A. Carosini, Firenze, Olschki, 1983 .

Plotinus, Plotini Opera, vol. 1. Porphyrii Vita Plotini. Enneades I-III, eds P. Henry, H.-R. Schwyzer, Oxford, Clarendon Press, 1964.

Proclus, In Timaeum Commentaria, ed. E. Diehl, 3 vols, Leipzig, Teubner, 1903-19o6.

Proclus, Théologie platonicienne. Livre II, eds H.-D. Saffrey, L.G. Westerink, Paris, Les Belles Lettres, 1974.

Proclus, De X dubitationibus circa providentiam, ed. D. Isaac, Trois études sur la providence. I. Dix problèmes concernant la providence, Paris, Les Belles Lettres, 1977.

Proclus, De providentia et fato, ed. D. Isaac, Trois études sur la providence. II. Providence, fatalité, liberté, Paris, Les Belles Lettres, 1979.

Proclus, De malorum subsistentia, ed. D. Isaac, Trois études sur la providence. III. De l'existence du mal, Paris, Les Belles Lettres, 1982.

Proclus, Commentaire sur le Parménide de Platon, Traduction de Guillaume de Moerbeke, ed. C. Steel, 2 vols, Leuven / Leiden, Leuven University Press / Brill, 1982-1985.

Proclus, Elementatio theologica, translata a Guillelmo de Moerbeke, ed. H. Boese, Leuven, Leuven University Press, 1987.

Remigius of Auxerre, Commentum in Martianum Capellam, ed. C.E. Lutz, 2 vols, Leiden, Brill, 1962-1965.

Thierry of Chartres, Commentaries on Boethius by Thierry of Chartres and His School, ed. N.M. Häring, Toronto, Pontifical Institute of Medieval Studies, 1971.

\section{Secondary Sources}

Allen, M.J.B., "Marsilio Ficino, Hermes Trismegistus and the Corpus Hermeticum", in J. Henry, S. Hutton (eds), New Perspectives on Renaissance Thought. Essays in the History of Science, Education and Philosophy in Memory of Charles B. Schmitt, London, Duckworth, 199o, p. 38-47. 
Allen, M.J.B., Synoptic Art. Marsilio Ficino on the History of Platonic Interpretation, Firenze, Olschki, 1998.

Allen, M.J.B., "Marsilio Ficino", in S. Gersh (ed.), Interpreting Proclus. From Antiquity to the Renaissance, Cambridge, Cambridge University Press, 2014, p. 353-379.

Allen, M.J.B., "Pythagoras in the Early Renaissance", in C.A. Huffman (ed.), A History of Pythagoreanism, Cambridge, Cambridge University Press, 2014, p. 435-453.

Arfé, P., "Ermete Trismegisto e Nicola Cusano", in P. Lucentini, I. Parri, V. Perrone Compagni (eds), Hermetism from Late Antiquity to Humanism. La tradizione ermetica dal mondo tardo-antico all'Umanesimo = Atti del Convegno internazionale di studi, Napoli 20-24 novembre 2001, Turnhout, Brepols, 2003, p. 223-243.

Baron, H. (ed.), Leonardo Bruni Aretino. Humanistisch-philosophische Schriften, mit einer Chronologie seiner Werke und Briefe, Leipzig / Berlin, Teubner, 1928.

Barozzi, L., R. Sabbadini, Studi sul Panormita e sul Valla, Firenze, Le Monnier, 1891.

Beierwaltes, W., "Cusanus und Proklos. Zum neuplatonischen Ursprung des non-aliud", in Nicolò Cusano agli inizi del mondo moderno. Atti del Congresso internazionale in occasione delVcentenario della morte diNicolò Cusano,Bressanone 6-10settembre 1964, Firenze, Sansoni, 1970, p. 137-140.

Beierwaltes, W., "Das seiende Eine. Zur neuplatonischen Interpretation der zweiten Hypothesis des platonischen Parmenides. Das Beispiel Cusanus", in G. Boss, G. Seel (eds), Proclus et son influence. Actes du Colloque de Neuchâtel, juin 1985, Zürich, Éditions du Grand Midi, 1987, p. 287-297.

Beierwaltes, W., "Centrum tocius vite. Zur Bedeutung von Proklos' Theologia Platonis im Denken des Cusanus", in A.-Ph. Segonds, C. Steel (eds), Proclus et la Théologie platonicienne. Actes du Colloque international de Louvain, 13-16 mai 1998, en l'honneur de H.-D. Saffrey et L.G. Westerink, Leuven / Paris, Leuven University Press / Brill, 20oo, p. 629-651.

Caiazzo, I., "Mains célèbres dans les marges des Commentarii in Somnium Scipionis de Macrobe", in D. Jacquart, C. Burnett (eds), Scientia in margine. Études sur les marginalia dans les manuscrits scientifiques du Moyen Âge à la Renaissance, Genève, Librairie Droz, 2005.

Federici Vescovini, G., Nicolas de Cues, Paris, Vrin, 2016.

Förstel, C., "Marsilio Ficino e il Parigino Greco di Plotino", in S. Gentile, S. Toussaint (eds), Marsilio Ficino, fonti, testi, fortuna. Atti del convegno internazionale, Firenze 1-3 ottobre 1999, Roma, Edizioni di Storia e Letteratura, 2006, p. 65-88.

Führer, M.L., "Cusanus Platonicus. References to the Term Platonici in Nicholas of Cusa", in S. Gersh, M.J.F.M. Hoenen (eds), The Platonic Tradition in the Middle Ages. A Doxographic Approach, Berlin / New York, De Gruyter, 2002, p. 345-370.

Gentile, S., C. Gilly (eds), Marsilio Ficino e il ritorno di Ermete Trismegisto. Marsilio Ficino and the Return of Hermes Trismegistus, Firenze, Centro Di, 1999.

Gersh, S., Middle Platonism and Neoplatonism. The Latin Tradition, 2 vols, Notre Dame, Indiana, University of Notre Dame Press, 1986. 
Gersh, S., "Berthold von Moosburg on the Content and Method of Platonic Philosophy", in J. Aertsen, K. Emery, A. Speer (eds), Nach der Verurteilung von 1277. Philosophie und Theologie an der Universität von Paris im letzten Viertel des 13. Jahrhunderts. Studien und Texte, Berlin / New York, De Gruyter, 2001, p. 493-503.

Gersh, S., "The First Principles of Latin Neoplatonism. Augustine, Macrobius, Boethius", in Vivarium 50(2012), p. 113-138.

Gersh, S., "Medieval Platonic Theology. Nicholas of Cusa as Summation and Singularity", in J. Hankins, F. Meroi (eds), The Rebirth of Platonic Theology. Proceedings of a Conference held at The Harvard University Centre for Italian Renaissance Studies (Villa I Tatti) and the Istituto Nazionale di Studi sul Rinascimento (Florence, 26-27 April, 2007), Firenze, Olschki, 2013, p. 15-45.

Gersh, S., "The Virtue of Absence. Nicholas of Cusa and the Historical Plato", in A. Balansard, I. Koch (eds), Lire les dialogues, mais lesquels et dans quel ordre? Définitions du corpus et interprétations de Platon, Sankt Augustin, Academia, 2013.

Gersh, S., "Nicholas of Cusa", in S. Gersh (ed.), Interpreting Proclus. From Antiquity to the Renaissance, Cambridge, Cambridge University Press, 2014, p. 318-349.

Gersh, S., "One Thousand Years of Proclus. An Introduction to his Reception", in S. Gersh (ed.), Interpreting Proclus. From Antiquity to the Renaissance, Cambridge, Cambridge University Press, 2014, p. 1-29.

Gersh, S., "Marsilio Ficino as Commentator on Plotinus. Some Case-Studies", in S. Gersh (ed.), Plotinus' Legacy. The Transformation of Platonism from the Renaissance to the Modern Era, Cambridge, Cambridge University Press, 2019, p. 19-43.

Gilly, C., "Die Überlieferung des Asclepius im Mittelalter", in R. van den Broek, C. van Heertum (eds), From Poimandres to Jacob Böhme. Gnosis, Hermetism and the Christian Tradition, Leiden, Brill, 200o, p. 336-367.

Hankins, J., Plato in the Italian Renaissance, 2 vols, Leiden / New York, Brill, 199 o.

Haubst, R., "Die Thomas- und Proklos-Exzerpte des 'Nicolaus Treverensis' in Codicillus Strassburg 84", in Mitteilungen und Forschungsbeiträge der CusanusGesellschaft 1(1961), p. 17-51.

Hicks, A., "Pythagoras and Pythagoreanism in Late Antiquity and the Middle Ages", in C.A. Huffman (ed.), A History of Pythagoreanism, Cambridge, Cambridge University Press, 2014, p. 416-434.

King, E., Supersapientia. A Study of the Expositio super Elementationem Theologicam Procli of Berthold von Moosburg, PhD diss., University of Cambridge, 2016.

Koch, J., Die Ars coniecturalis des Nikolaus von Kues, Cologne, Westdeutscher Verlag, 1956.

Kristeller, P.O., Supplementum Ficinianum, 2 vols, Firenze, Olschki, 1937.

Lucentini, P., Perrone Compagni, V., "I manoscritti dei testi ermetici latini", in P. Lucentini, I. Parri, V. Perrone Compagni (eds), Hermetism from Late Antiquity to Humanism. La tradizione ermetica dal mondo tardo-antico all'Umanesimo = Atti del 
Convegno internazionale di studi, Napoli 20-24 novembre 2001, Turnhout, Brepols, 2003, p. 715-745.

Ludueña, E., La recepción de Eriúgena en Bertoldo de Moosburg. Un aporte sobre la Escuela de Colonia, Saarbrücken, Publicia, 2013.

Megna, P., "Marsilio Ficino e il Commento al Timeo di Proclo", in Studi medievali e umanistici 1(2003), p. 93-135.

Megna, P., "Per Ficino e Proclo", in F. Bausi, V. Fera (eds), Laurentia Laurus. Per Mario Martelli, Messina, Centro interdipartimentale di studi umanistici, 2004, p. 313-362.

Minazzoli, A., "L'héritage du Corpus Hermeticum dans la philosophie de Nicolas de Cues", in La Ciudad de Dios 205(1992), p. 101-122.

Monfasani, J., "Marsilio Ficino and the Plato-Aristotle Controversy", in M.J.B. Allen, V. Rees (eds), Marsilio Ficino. His Theology, his Philosophy, his Legacy, Leiden, Brill, 2OO2, p. 179-2O2.

Porreca, D., "Hermes Trismegistus in Thomas of York. A 13th-Century Witness to the Prominence of an Ancient Sage", in Archives d'histoire doctrinale et littéraire du Moyen Âge 72(2005), p. 147-275.

Robichaud, D., "Fragments of Marsilio Ficino's Translations and Use of Proclus' Elements of Theology and Elements of Physics. Evidence and Study", in Vivarium 54(2016), p. 46-107.

Ruocco, I. (ed.), Il Platone latino. Il Parmenide. Giorgio di Trebisonda e il cardinale Cusano, Firenze, Olschki, 2003.

Saffrey, H.-D., "Notes platoniciennes de Marsile Ficin dans un manuscrit de Proclus (Cod. Riccardianus 70)", in Bibliothèque d'Humanisme et de Renaissance 21(1959), p. $161-184$.

Sannino, A., "Berthold of Moosburg's Hermetic Sources", in Journal of the Warburg and Courtauld Institutes 63(2000), p. 243-258.

Sannino, A., "Il concetto ermetico di natura in Bertoldo di Moosburg", in P. Lucentini, I. Parri, V. Perrone Compagni (eds), Hermetism from Late Antiquity to Humanism. La tradizione ermetica dal mondo tardo-antico all'Umanesimo = Atti del Convegno internazionale di studi, Napoli 20-24 novembre 2001, Turnhout, Brepols, 2003, p. 203-221.

Sannino, A., "Il Liber viginti quattuor philosophorum nella metafisica di Bertoldo di Moosburg", in A. Beccarisi, R. Imbach, P. Porro (eds), Per perscrutationem philosophicam. Neue Perspektiven der mittelalterlichen Forschung. Loris Sturlese zum 6o. Geburtstag gewidmet, Hamburg, Meiner, 2008, p. 252-272.

Steel, C., "Ficino and Proclus. Arguments for the Platonic Doctrine of the Ideas", in J. Hankins, F. Meroi (eds), The Rebirth of Platonic Theology. Proceedings of a Conference held at The Harvard University Centre for Italian Renaissance Studies (Villa I Tatti) and the Istituto Nazionale di Studi sul Rinascimento (Florence, 26-27 April, 2007), Firenze, Olschki, 2013, p. 63-118. 
Sturlese, L., "Saints et magiciens. Albert le Grand en face d'Hermès Trismégiste", in Archives de philosophie 43(1980), p. 615-634.

Tigerstedt, E.N., The Decline and Fall of the Neoplatonic Interpretation of Plato. An Outline and Some Observations, Helsinki, Societas Scientiarum Fennica, 1974.

Toussaint, S., "Mystische Geometrie und Hermetismus in der Renaissance. Ficinus und Cusanus", in Perspektiven der Philosophie 26(200o), p. 339-356. 